\title{
Sensitization of melanoma cells for TRAIL-induced apoptosis by BMS-345541 correlates with altered phosphorylation and activation of Bax
}

\author{
A Berger ${ }^{1}$, S-A Quast ${ }^{1}$, M Plötz ${ }^{1}$, A Kammermeier ${ }^{1}$ and J Eberle ${ }^{\star, 1}$
}

Resistance to TRAIL (TNF-related apoptosis-inducing ligand)- induced apoptosis limits its therapeutic use. Different strategies of TRAIL sensitization and a dependency on Bax have been reported, but common principles of TRAIL resistance and the way of Bax activation remained poorly understood. Applying a melanoma model of TRAIL-sensitive and -resistant cell lines, efficient sensitization for TRAIL-induced apoptosis is demonstrated by the kinase inhibitor BMS-345541 ( $N$-(1,8dimethylimidazo(1,2-a)quinoxalin-4-y|)-1,2-ethanediamine hydrochloride), which targets $\mid \kappa B$ (inhibitor of $\kappa B$ proteins) kinase $\beta$ $(\mathrm{IKK} \beta)$. This effect was completely abrogated by Bax knockout as well as by Bcl-2 overexpression, in accordance with a Bax dependency. Early loss of the mitochondrial membrane potential, release of cytochrome $c$ and Smac (second mitochondriaderived activator of caspases) clearly indicated the activation of mitochondrial apoptosis pathways. Of note, BMS-345541 alone resulted in an early Bax activation, seen by conformational changes and by Bax translocation. The synergistic effects can be explained by Bid activation through TRAIL, which inhibits Bcl-2, and the activation of Bax through BMS-345541. The critical roles of XIAP (X-chromosome-linked inhibitor of apoptosis protein), Smac and Bid were clearly proven by overexpression and siRNA knockdown, respectively. The way of Bax activation by BMS-345541 was unraveled by establishing new assays for Bax activation. These showed reduction of the inactivating Bax phosphorylation at serine-184, while the activating Bax phosphorylation at threonine-167 was enhanced. Thus, modulation of Bax phosphorylation appeared as tightly related to TRAIL sensitivity/resistance in melanoma cells, and therapeutic strategies may be considered.

Cell Death and Disease (2013) 4, e477; doi:10.1038/cddis.2012.198; published online 24 January 2013

Subject Category: Cancer

Metastatic melanoma is characterized by unbroken high mortality, ${ }^{1}$ and its pronounced resistance to chemotherapy and an antitumor immune response is related to defective proapoptotic signaling. ${ }^{2,3}$ Thus, overcoming apoptosis deficiency represents an important therapeutic goal. The death ligand TRAIL (TNF-related apoptosis-inducing ligand), which induces apoptosis via death receptors DR4 and DR5, represents a promising therapeutic strategy, due to selective targeting of cancer cells. ${ }^{4}$

In melanoma, we had previously shown functional activity of TRAIL receptors; ${ }^{5}$ however, some melanoma cell lines showed permanent TRAIL resistance and others developed inducible resistance upon TRAIL treatment. ${ }^{6}$ Inducible resistance was related to the downregulation of TRAIL receptors, initiator caspases and proapoptotic $\mathrm{Bcl}-2$ proteins, ${ }^{6,7}$ while the causes of permanent resistance in melanoma remained elusive.

Two major proapoptotic pathways have been described. Extrinsic pathways are initiated by binding of death ligands (TNF- $\alpha$, CD95L/FasL or TRAIL) to death receptors, leading to the formation of death-inducing signaling complexes (DISC) and activation of initiator caspase-8 and $-10 .^{8}$ Intrinsic pathways are initiated by cellular and DNA damage and result in proapoptotic mitochondrial activation. ${ }^{9}$ Both pathways may meet at the mitochondria owing to caspase-8-mediated processing and activation of the proapoptotic $\mathrm{Bcl}-2$ protein Bid, resulting in truncated Bid (tBid). ${ }^{10}$

Key events of intrinsic pathways are depolarization of the mitochondrial membrane potential $(\Delta \psi \mathrm{m})$ and mitochondrial outer membrane permeabilization (MOMP), leading to a release of cytochrome $c$, Smac (second mitochondria-derived activator of caspases) and AIF (apoptosis-inducing factor). Whereas cytochrome $c$ activates caspase- 9 via the apoptosome, Smac functions as an antagonist of cellular inhibitor of apoptosis proteins (clAPs; e.g. X-chromosome-linked inhibitor of apoptosis protein (XIAP) and survivin), which themselves block caspase activity. AIF may induce apoptosis in a caspase-independent manner. ${ }^{11-13}$

Mitochondrial apoptosis pathways are controlled by $\mathrm{Bcl}-2$ proteins, enclosing antiapoptotic (e.g. Bcl-2 and $\mathrm{Mcl}-1$ ),

\footnotetext{
${ }^{1}$ Department of Dermatology and Allergy, Skin Cancer Center, University Medical Center Charité, Berlin, Germany

*Corresponding author: J Eberle, Department of Dermatology and Allergy, Charité-Universitätsmedizin Berlin, Skin Cancer Center, Charitéplatz 1, Berlin 10117, Germany. Tel: + 4930450 518383; Fax: + 4930450 518984; E-mail: juergen.eberle @charite.de

Keywords: Bax; TRAIL; Bid; Smac; BMS-345541; melanoma

Abbreviations: $\Delta \psi \mathrm{m}$, mitochondrial membrane potential; AIF, apoptosis-inducing factor; cFLIP, cellular FLICE inhibitory protein; cIAP, cellular inhibitor of apoptosis protein; GAPDH, glucose-6-phosphate dehydrogenase; IKK, I- $\kappa$ B kinase; I- $\kappa$ B, inhibitor of $\kappa$ B proteins; LDH, lactate dehydrogenase; Smac, second mitochondriaderived activator of caspases; tBid, truncated Bid; TRAIL, TNF-related apoptosis-inducing ligand; VDAC, voltage-dependent anion channel; XIAP, X-chromosome-linked inhibitor of apoptosis protein

Received 10.8.12; revised 27.11.12; accepted 28.11.12; Edited by T Brunner
} 
proapoptotic multidomain (Bax and Bak) and proapoptotic BH3-only proteins (e.g. Bid). ${ }^{14}$ Initiator caspase-8, -9 and -10 activate downstream effector caspases as caspase-3, which finally cleave a large number of death substrates to set apoptosis into work. ${ }^{15}$

Also, activation of nuclear factor $-\kappa \mathrm{B}(\mathrm{NF}-\kappa \mathrm{B})$ was related to apoptosis resistance of cancer cells. ${ }^{16}$ Thus, the kinase inhibitor BMS-345541 ( $N$-(1,8-dimethylimidazo(1,2-a)quinoxalin-4-yl)-1,2-ethanediamine hydrochloride) has been developed as $\mathrm{I}-\kappa \mathrm{B}$ (inhibitor of $\kappa \mathrm{B}$ proteins) kinase $\beta$ (IKK $\beta$ ), which induces degradation of $\mathrm{I}_{\kappa} \mathrm{B} \alpha$, the inhibitor of $\mathrm{NF}-\kappa \mathrm{B} .{ }^{17}$ The role of NF- $\kappa$ B in TRAIL sensitivity of melanoma cells remained in question. ${ }^{6,18}$ By screening for strategies to sensitize melanoma cells for TRAIL, we identified the IKK inhibitor BMS345541, which had shown antitumor activity already in different tumor models. ${ }^{19,20}$ We therefore characterized the molecular mechanisms and found that BMS-345541 resulted in an early activation of Bax via its altered phosphorylation, whereas NF- $\kappa \mathrm{B}$ may exert its effects only at later steps.

\section{Results}

Direct effects of BMS-345541 on apoptosis and NF- $\kappa$ B activation. The kinase inhibitor BMS-345541 was evaluated for identifying strategies to overcome melanoma cell resistance to TRAIL-induced apoptosis. Alone, BMS-345541 resulted in a partial $\mathrm{G} 2$ arrest, seen at $24 \mathrm{~h}$ in melanoma cell lines A-375, Mel-HO, MeWo and Mel-2a (Figure 1a). Higher concentrations $(>10 \mu \mathrm{M})$ also resulted in induction of apoptosis, whereas only moderate proapoptotic effects were seen with $2-5 \mu \mathrm{M}$ (Figure 1b). Some enhancement of cytotoxicity (lactate dehydrogenase (LDH) release) appeared in parallel with apoptosis (Figure 1c).

The NF- $\kappa$ B inhibitory activity of BMS-345541 was proven in combinations with TNF- $\alpha(10 \mathrm{ng} / \mathrm{ml})$. Thus, TNF- $\alpha$-mediated degradation of $\mathrm{I}-\kappa \mathrm{B} \alpha(15 \mathrm{~min})$, nuclear translocation of NF- $\kappa \mathrm{B}$ p65 and enhanced nuclear p65 DNA-binding activity (1 h) were suppressed in A-375 by BMS-345541 (Figures 1d and f).

Nuclear p65 DNA-binding activity was also enhanced by TRAIL (fourfold at $1 \mathrm{~h}$ ), which was again reduced by BMS-345541 (Figure 1f). However, no enhancement of nuclear p65 or decrease of $\mathrm{I}-\kappa \mathrm{B} \alpha$ was seen in response to TRAIL at early times, suggesting other ways of $\mathrm{NF}-\kappa \mathrm{B}$ activation (Figure 1e). Nevertheless, BMS-345541 decreased nuclear levels of p65 at $16 \mathrm{~h}$ (Figure $1 \mathrm{~g}$ ), which however cannot explain the early effects of BMS-345541 shown below.

Sensitization for death ligand-induced apoptosis. Combinations of BMS-345541 and TRAIL were investigated in TRAIL-sensitive (A-375, Mel-HO), permanent TRAILresistant (MeWo, Mel-2a) and in TRAIL-selected melanoma cell lines with induced resistance (A-375-TS, Mel-HO-TS). Whereas only moderate direct proapoptotic effects were seen with low-dose BMS-345541 $(2-5 \mu \mathrm{M})$ or TRAIL $(20 \mathrm{ng} / \mathrm{ml})$, apoptosis was strongly enhanced by the combinations. For combined treatment, BMS-345541 and TRAIL were given together for the same times. Thus, $35-40 \%$ of apoptosis was obtained in sensitive A-375 and Mel-HO at $24 \mathrm{~h}$, and $15-25 \%$ of apoptosis was obtained in previously resistant melanoma cells (Figure $2 \mathrm{a}$ ).
Apoptotic cells were identified in cell cycle analyses because of fragmented DNA (sub-G1 cells; Figure 2b). Similar enhancement of apoptosis ( $>40 \%$ at $24 \mathrm{~h}$ ) was seen in A-375 and Mel-HO, when BMS-345541 was combined with an agonistic CD95 antibody $(\mathrm{CH}-11,50 \mathrm{ng} / \mathrm{ml}$; Figure 2c), but $\mathrm{CH}-11$-resistant cell lines could not be sensitized (data not shown). A concentration of $5 \mu \mathrm{M}$ worked well for all cell lines, resulting in enhanced TRAIL sensitivity. As A-375 showed higher sensitivity to $2 \mu \mathrm{M}$ BMS-345541 a concentration of $2 \mu \mathrm{M}$ was used for these cells in the following.

Typical characteristics of apoptosis (nuclear fragmentation and chromatin condensation) and comparable apoptotic rates (20-40\%, at $24 \mathrm{~h}$ ) were evident in A-375 and A-375-TS after bisbenzimide staining (Figures $2 \mathrm{~d}$ and e). Induced apoptosis exerted a strong impact on cell proliferation, as monitored by real-time cell analysis. Thus, cell indices corresponding to attached cell numbers were decreased by three- to sevenfold at $72 \mathrm{~h}$ of treatment (Figure 2f).

Caspase involvement. In A-375, the extrinsic caspase cascade was activated by TRAIL at $16 \mathrm{~h}$, evident by cleavage products of caspase- 8 (18, 41 and $43 \mathrm{kDa})$ and caspase- 3 $(15,17$ and $20 \mathrm{kDa})$, as well as by loss of the proforms (57 and $35 \mathrm{kDa}$ ). Degradation of Bid and caspase-9 proforms (22 and $47 \mathrm{kDa}$ ) also indicated proapoptotic mitochondrial activation (Figure 3a). Because of only moderate apoptosis induction in response to TRAIL (10\%; Figure 2a), the caspase cascade seemed to be blocked at a later step, which was suggestive for the role of clAPs. Upon combination with BMS-345541, this blockage was overcome, as seen by enhanced processing of caspase- 9 and -3 (Figure 3a).

Also in resistant cells (A-375-TS, Mel-2a and MeWo), some caspase-8 processing was seen in response to TRAIL at $16 \mathrm{~h}$. The lack of apoptotic response correlated with suppressed caspase-3 processing in response to TRAIL, which again was strongly enhanced by BMS-345541. Reduced levels of caspase- 9 and Bid proforms were seen in A-375-TS already with TRAIL, whereas in permanent resistant Mel-2a and MeWo, there was only a tendency in response to combination treatment. In contrast, BMS-345541 $(5 \mu \mathrm{M})$ alone remained without effect (Figure 3a). The decisive role of caspases was demonstrated by the pancaspase inhibitor zVAD-fmk, which suppressed apoptosis induction by BMS-345541/TRAIL, whereas the direct proapoptotic effects of BMS-345541 were not affected (Figure 3b).

The expression of antiapoptotic $\mathrm{Bcl}-2$ proteins (Bcl-2 and $\mathrm{Mcl}-1$ ), proapoptotic Bcl-2 proteins (Bax and Bak) and inhibitory proteins of caspase cascades (cellular FLICE inhibitory protein (cFLIP), XIAP and survivin) was investigated by western blotting in A-375 and A-375-TS at 8 and $16 \mathrm{~h}$ of treatment. Whereas no significant differences were seen for cFLIP, Bax, Bak, Bcl-2 and survivin, downregulation of $\mathrm{Mcl}-1$ and XIAP was found at $16 \mathrm{~h}$ of combination treatment. This was however not seen at $8 \mathrm{~h}$ and was prevented by the caspase inhibitor zVAD-fmk (Figure 3c). Both proteins may thus be employed at later times in enhancing apoptosis, but their regulation may not explain the early regulatory steps.

Decisive roles of Bcl-2 and Bax. Indicating the activation of mitochondrial apoptosis pathways, strong decrease 
a
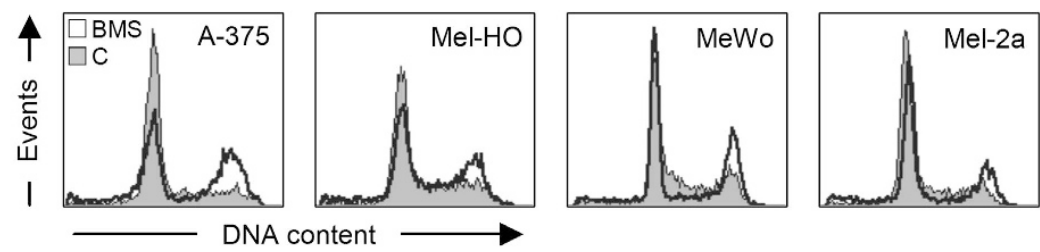

b

A-375

Mel-HO

MeWo

Mel-2a
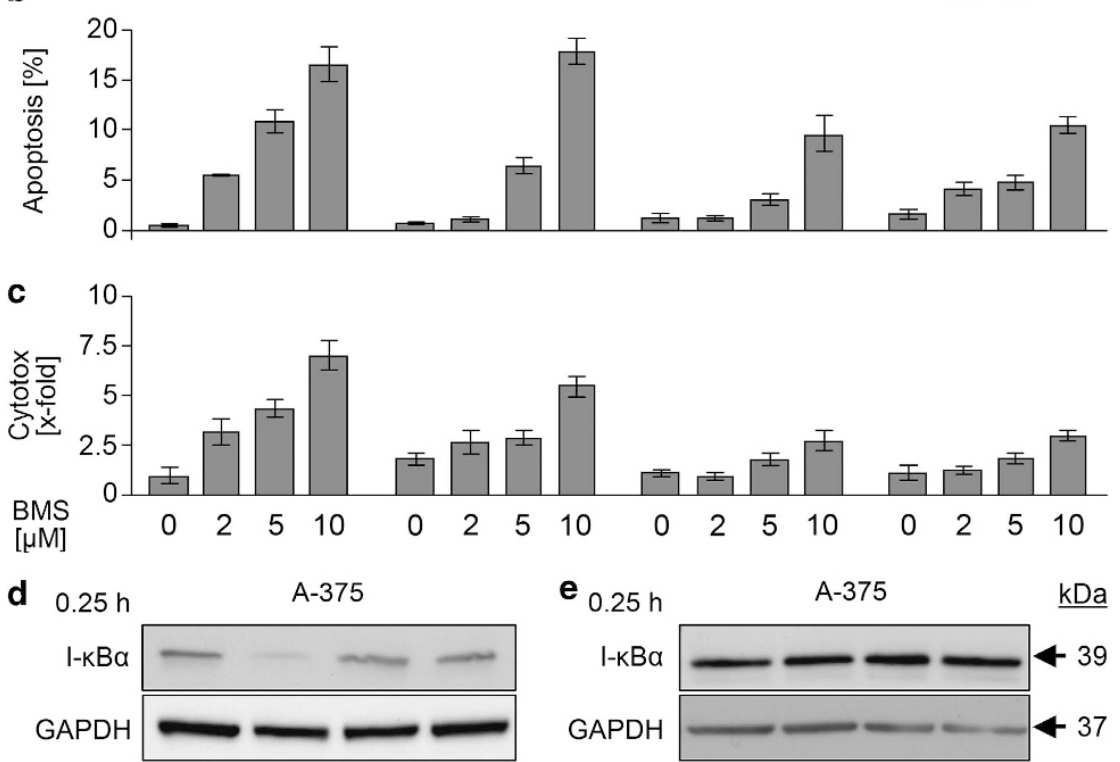

$\mathbf{e}_{0.25 \mathrm{~h}}$

A-375

$\underline{\mathrm{kDa}}$
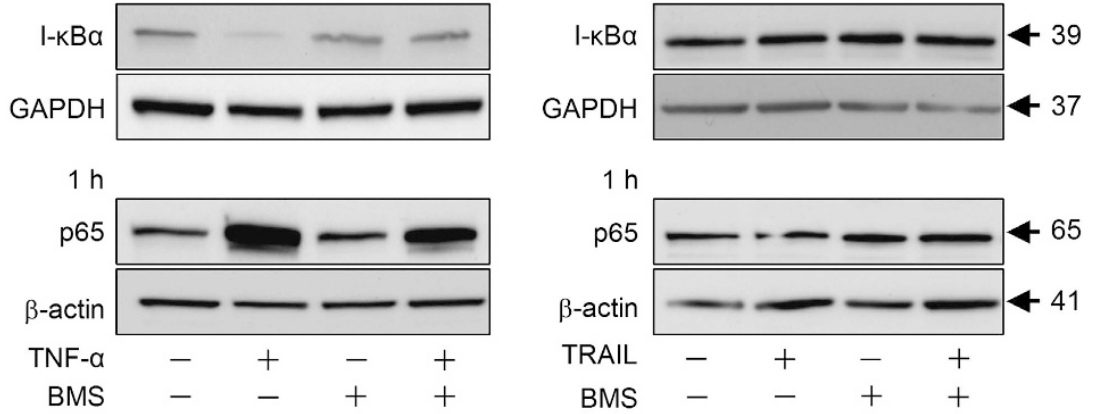

f

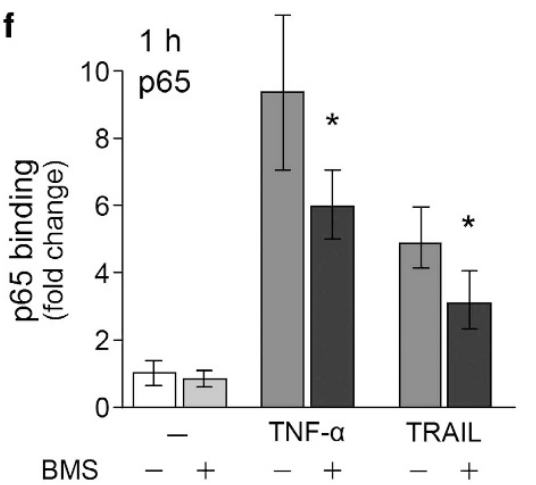

g

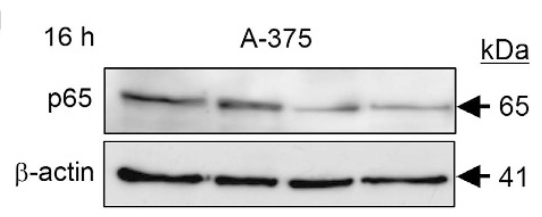

A-375-TS

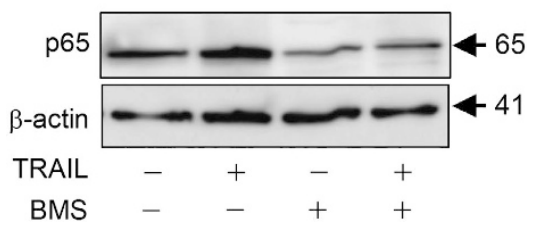

Figure 1 Antiproliferative effects by BMS-345541. (a) Cell cycle analysis of melanoma cell lines A-375, Mel-HO, MeWo and Mel-2a. Cells treated with BMS-345541 (2 $\mu$ M, open graphs) were compared with dimethylsulfoxide (DMSO)-treated controls (filled graphs). (b) Apoptosis induction (\% of sub-G1 cells) and (c) cytotoxicity (LDH release) is shown in response to increasing concentrations of BMS-345541 (2-10 $\mu \mathrm{M})$. (a-c) At least two independent experiments with triplicates revealed comparable results. (d) Total protein levels of $\mathrm{I}-\kappa \mathrm{B} \alpha$ and nuclear levels of $\mathrm{p} 65$ were determined by western blotting in A-375 cells treated with TNF- $\alpha(10 \mathrm{ng} / \mathrm{ml}$ and BMS-345541 $(2 \mu \mathrm{M})$. Total proteins were extracted at $0.25 \mathrm{~h}$ and nuclear extracts at $1 \mathrm{~h}$ of treatment. (e) Proteins and nuclear extracts were isolated at the same times after treatment with TRAIL and BMS-345541. (f) Relative p65 DNA-binding capacity in nuclear extracts of A-375, treated for $1 \mathrm{~h}$ with TNF- $\alpha$ ( $20 \mathrm{ng} / \mathrm{ml})$, TRAlL (10 ng/ml) and BMS-345541 (2 $\mu \mathrm{M})$, was quantified by enzyme-linked immunosorbent assay (ELISA). Means and S.D.'s were calculated from three independent experiments, and statistical significance is indicated $\left({ }^{*} P<0.05\right)$. (g) Nuclear extracts were analyzed by western blotting for p65 in A-375 and A-375-TS at $16 \mathrm{~h}$ of treatment with TRAIL (20 ng/ml) and BMS-345541 (A-375, $2 \mu \mathrm{M} ; \mathrm{A}-375-\mathrm{TS}$, $5 \mu \mathrm{M})$. (d, e, g) At least two independent experiments revealed largely comparable results; equal loading was proven by GAPDH, $\beta$-actin and Ponceau staining 

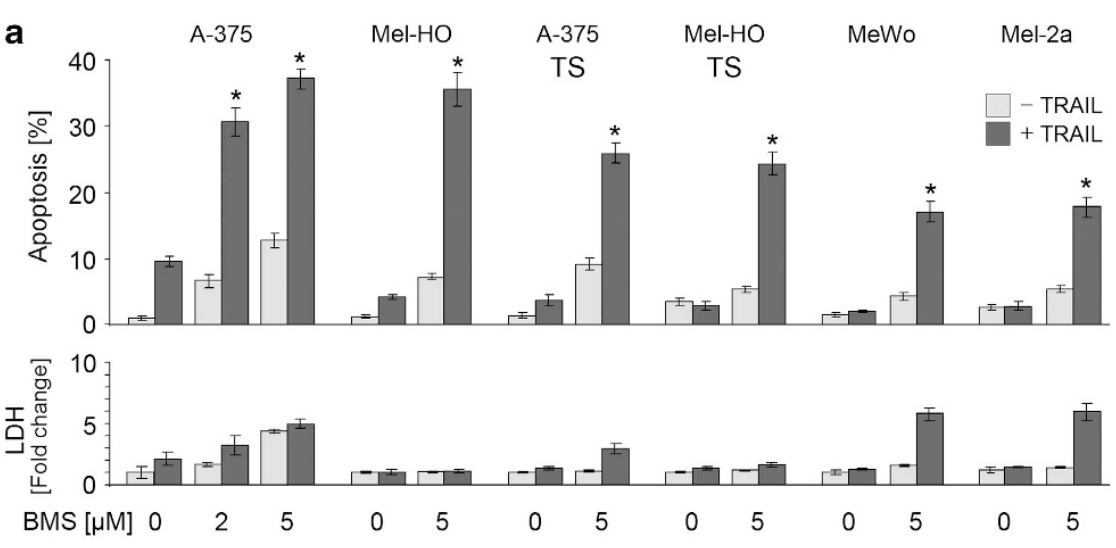

b

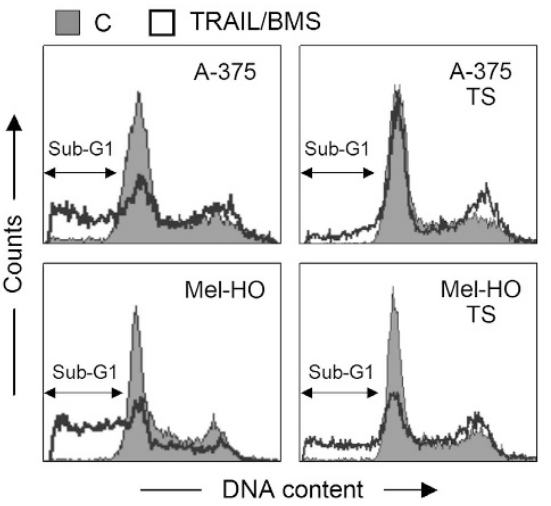

c

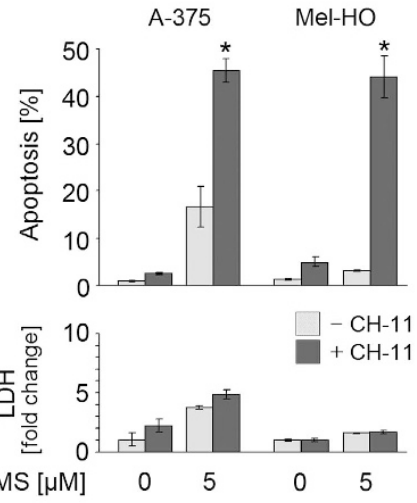

d

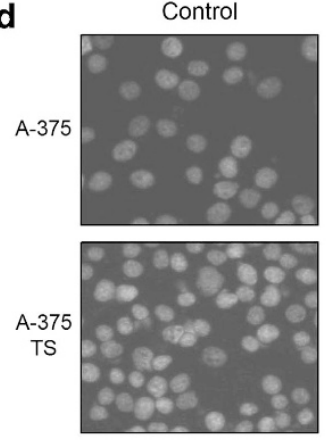

BMS/TRAIL
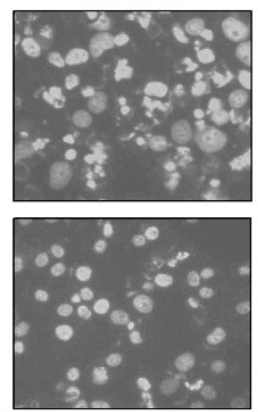

A-375 A-375-TS

e

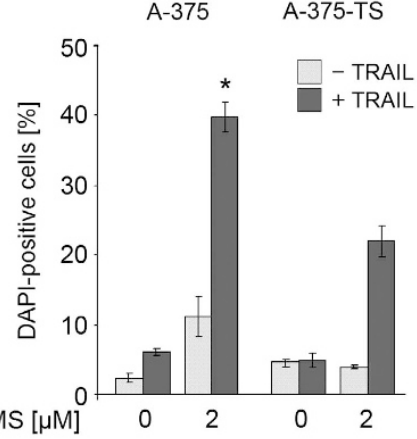

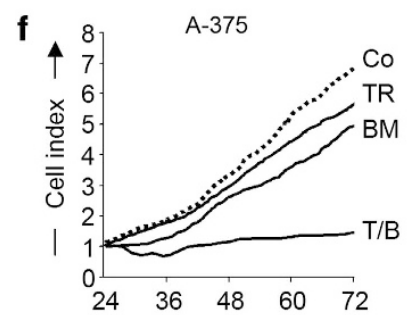
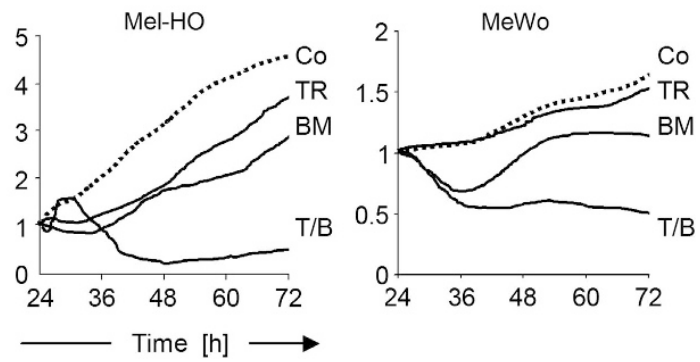

Figure 2 Sensitization of melanoma cells for death ligand-induced apoptosis. (a) Apoptosis (sub-G1 populations) and cytotoxicity (LDH release) were determined in melanoma cell lines in response to treatment with $2-5 \mu \mathrm{M}$ BMS-345541 \pm TRAlL $(20 \mathrm{ng} / \mathrm{ml})$. (b) Examples of cell cycle analyses are shown. BMS-345541/TRAlL-treated cells (open graphs) were compared with DMSO treated controls (filled graphs). (c) Apoptosis (sub-G1 cells) and cytotoxicity (LDH release) are shown in Mel-HO and A-375 in response to BMS-345541 $(5 \mu \mathrm{M}) \pm \mathrm{CH}-11(50 \mathrm{ng} / \mathrm{ml})$. (d) Photographs of bisbenzimide-stained A-375 and A-375-TS cells treated for $24 \mathrm{~h}$ with BMS-345541/TRAlL. (e) Quantitative evaluations of proportions of cells with fragmented nuclei or condensed chromatin are shown. (f) Real-time cell analyses (xCELLigence) of melanoma cell lines treated with TRAIL (20 ng/ml, TR), BMS-345541 (2 $\mu \mathrm{M}, \mathrm{BM})$ or the combination (T/B) were compared with control cells (Co). (a, c, e, f) Means and S.D.'s of triplicate values of representative experiments are shown. All experiments were performed at least two times, which revealed highly comparable results. Statistical significance is indicated $\left({ }^{\star} P<0.05\right)$, comparing the combination treatment with BMS-345541 alone 

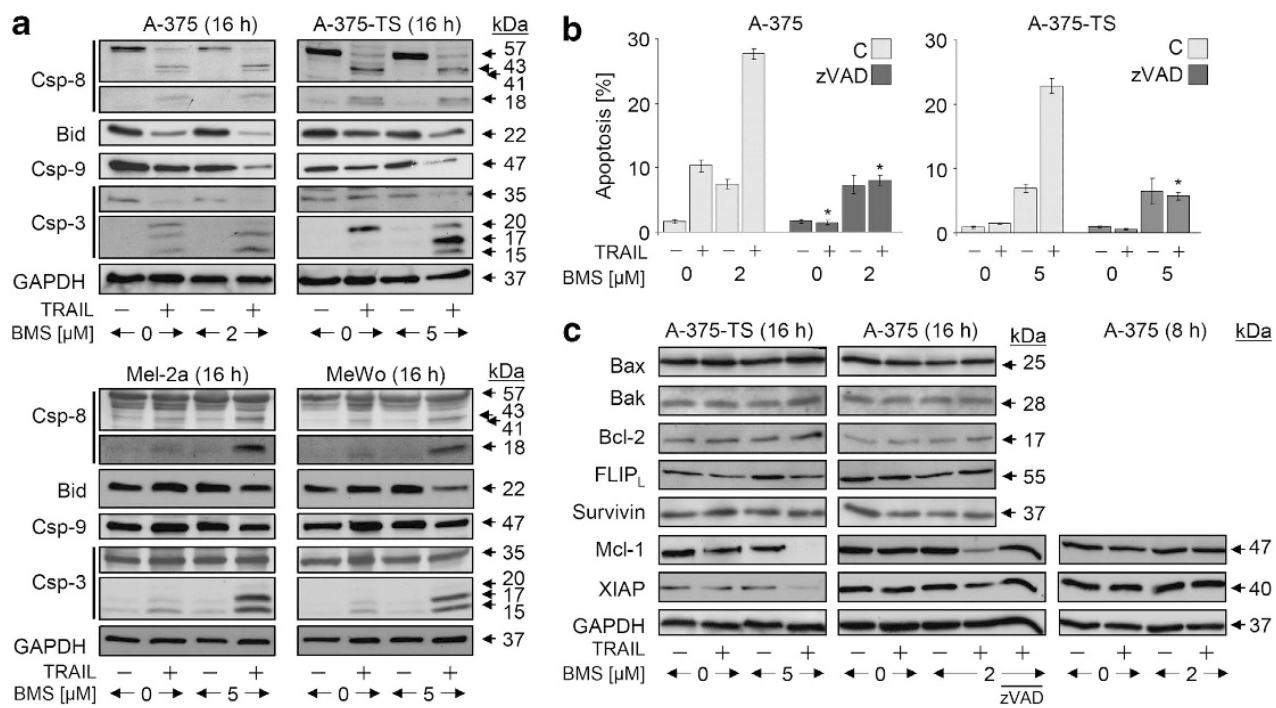

Figure 3 Caspase activation in response to BMS-345541 and TRAIL. (a) Processing of caspase-8, -9 and -3 , as well as of Bid was determined by western blotting in A-375, A-375-TS, MeWo and Mel2a treated with TRAIL (20 ng/ml) and/or BMS-345541 (A-375: $2 \mu \mathrm{M}$; other cells: $5 \mu \mathrm{M})$. (b) A-375 and A-375-TS were treated in addition to TRAIL and BMS-345541 with the pancaspase inhibitor ZVAD-fmk (10 $\mu \mathrm{M}, 1 \mathrm{~h}$ pretreatment), and apoptosis (sub-G1 cells) was determined after $24 \mathrm{~h}$ (mean values and S.D.'s of two independent experiments, each with triplicates). Significant inhibition of apoptosis by ZVAD-fmk is indicated ( $\left.{ }^{*} P<0.05\right)$. (c) Expression of apoptosis regulators was determined by western blotting in A-375 and A-375-TS in response to BMS-345541 \pm TRAIL (20 ng/ml) of 8 and $16 \mathrm{~h}$ of treatment. For the analysis of Mcl-1 and XIAP expression at $16 \mathrm{~h}$, cells were treated in addition with the pancaspase inhibitor ZVAD. (a-c) At least two independent experiments revealed comparable results

of $\Delta 4 \mathrm{~m}(>90 \%)$ was seen at $24 \mathrm{~h}$ in A-375 and in A-375-TS in response to BMS-345441/TRAIL, whereas BMS-345441 alone remained without effect on $\Delta \psi \mathrm{m}$, and TRAIL affected only $18 \%$ of A-375 cells. Time kinetic analyses revealed $\Delta \psi \mathrm{m}$ loss as an early step ( $2 \mathrm{~h})$, before apoptosis was induced (Figure $4 \mathrm{a})$. An initial phase $(2-4 \mathrm{~h})$, when $20 \%$ of cells had lost $\Delta \psi \mathrm{m}$ without induction of apoptosis, was distinguished from an amplification phase (8-24h), when apoptosis increased in parallel with further loss of $\Delta \psi \mathrm{m}$ (Figure $4 \mathrm{~b}$ ). The decisive role of mitochondria was supported by $\mathrm{Bcl}-2$ overexpression in A-375 (A375-Bcl-2), which completely prevented apoptosis by BMS-345441/TRAIL (Figure 4c). This was accompanied by preventing $\Delta \psi \mathrm{m}$ loss in the initial as well as in the amplification phase (Figure 4d).

Bax and Bak activities were distinguished in an HCT-116 cell model, which consisted of $\mathrm{Bax}^{+} \mathrm{Bak}^{+}$parental cells, Bax knockout (Bax-KO), Bak knockdown and double knockdown cells. Whereas apoptosis was efficiently induced by TRAIL/ BMS-345441 in $\mathrm{Bax}^{+} \mathrm{Bak}^{+}$and Bak knockdown cells, it was completely prevented by Bax-KO (Figure 4e). In parallel, loss of $\Delta \psi \mathrm{m}$ was strongly diminished (Figure $4 \mathrm{f}$ ).

Critical roles of Smac and tBid. Release of mitochondrial apoptogenic factors, cytochrome $c$, AIF and Smac, was seen already at $2 \mathrm{~h}$ of combination treatment (Figure $5 \mathrm{a}$ ). No further increase was seen at 4 or $16 \mathrm{~h}$ (data not shown), characterizing the mitochondrial response as an initial step. The limiting role of clAPs was investigated by plasmidmediated XIAP overexpression in A-375. Proving the significant antiapoptotic role of XIAP in this setting, its overexpression strongly diminished BMS-345541/ TRAIL-induced apoptosis by $60 \%$, as compared with mocktransfected cells (Figure 5b). Thus, Smac represented the suitable candidate for explaining apoptosis induction. Indeed,
siRNA-mediated Smac knockdown decreased apoptosis by BMS-345441/TRAIL to levels that resulted from BMS345441 itself (Figure 5c). Smac knockdown also abolished $\Delta \psi \mathrm{m}$ loss in the amplification phase ( $24 \mathrm{~h}$ ) but not in the early phase (2h) (Figure 5d).

Caspase-8-mediated processing of Bid to tBid represents a suitable way for connecting death receptor signaling and mitochondria. The function of Bid was therefore investigated by siRNA knockdown. Again, apoptosis was decreased to levels that resulted from BMS-345541 treatment alone (Figure $6 \mathrm{a}$ ). Here, loss of $\Delta \psi \mathrm{m}$ was completely abolished, both in the initial phase ( $2 \mathrm{~h}$ ) and the amplification phase $(24 \mathrm{~h}$; Figure $6 \mathrm{~b}$ ), thus characterizing Bid function as an upstream regulatory step.

Activation of Bax by BMS-345541 through altered phosphorylation. Bax activation was monitored in response to moderate concentrations of BMS-345541. As demonstrated by $\mathrm{N}$-terminus-specific antibodies in A-375 and A-375-TS, significant Bax activation was evident already at $1 \mathrm{~h}$ in response to BMS-345541 alone (Figure 7a). This correlated with Bax mitochondrial translocation at $2 \mathrm{~h}$ (Figure 7b). Highly suggestive for cooperative activities, tBid also located to mitochondria at $2 \mathrm{~h}$ in response to TRAIL. At this time, there was already some processing of caspase-8, although only weak (Figure 7b). Thus at early times of combination treatment, Bid and Bax were both activated (Figure 7b).

For understanding the link how BMS-345541 may influence Bax activation, we established assays for monitoring Bax phosphorylation at serine-184 (Ser184) and threonine-167 (Thr167). They were based on cell permeabilization and staining with phosphorylation-specific antibodies. As shown by subsequent flow cytometry, significant reduction of the 


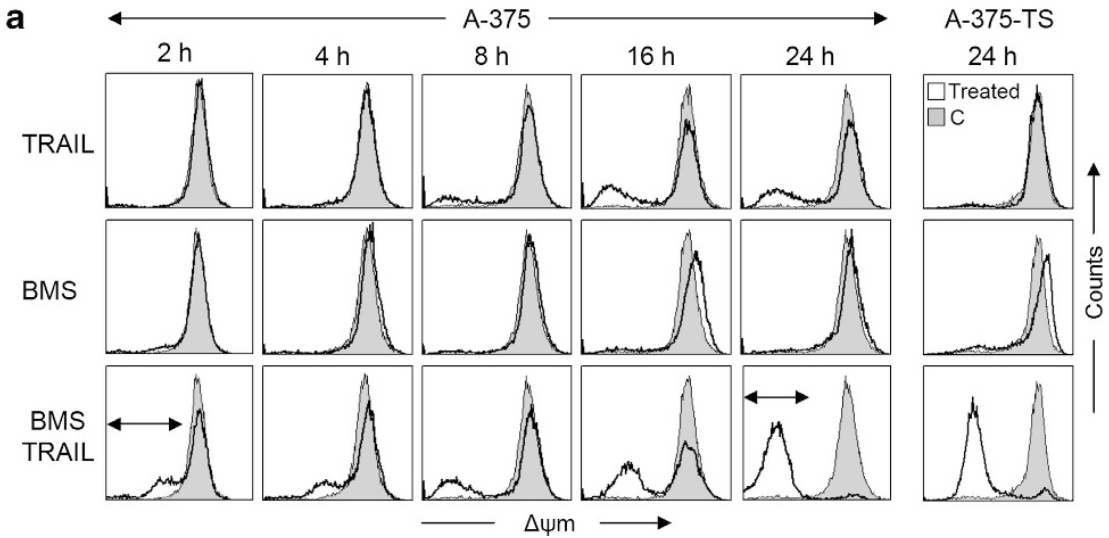

b
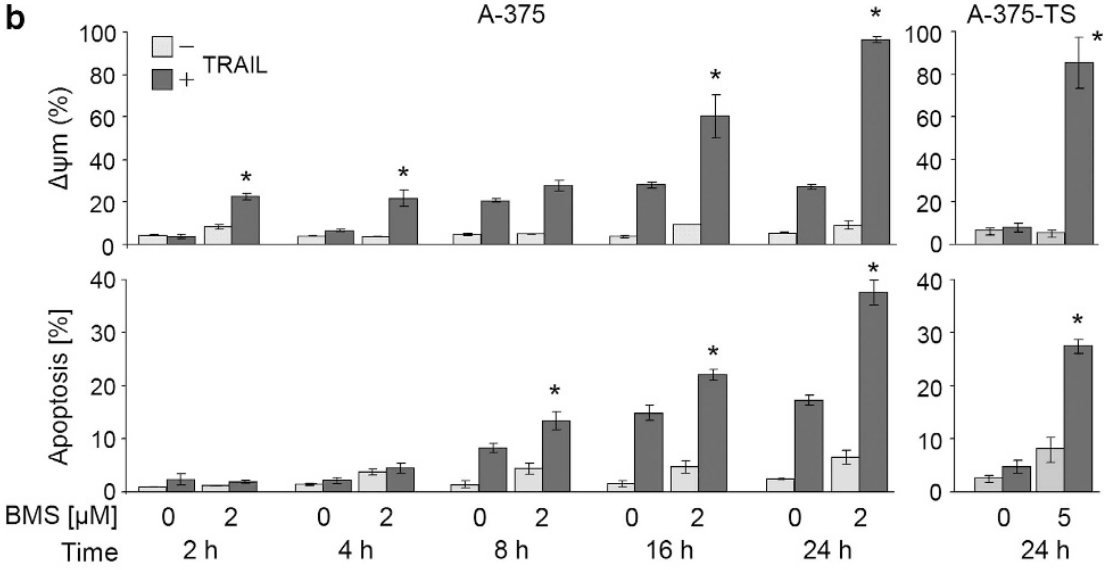

C
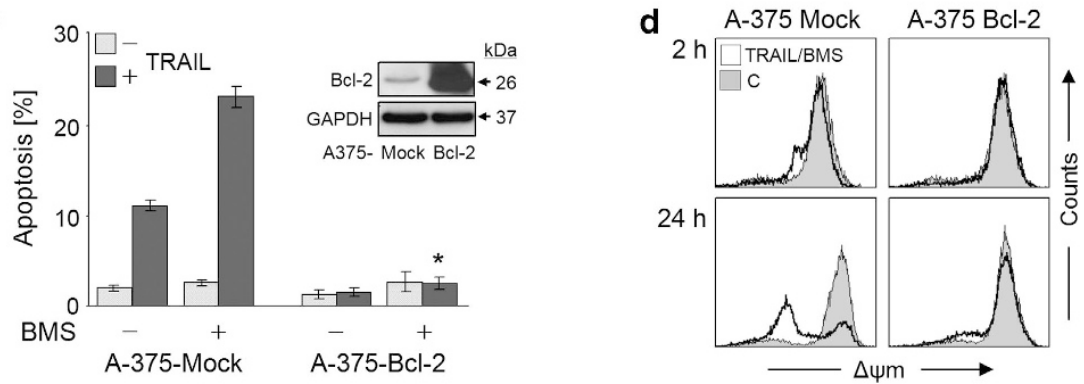

e
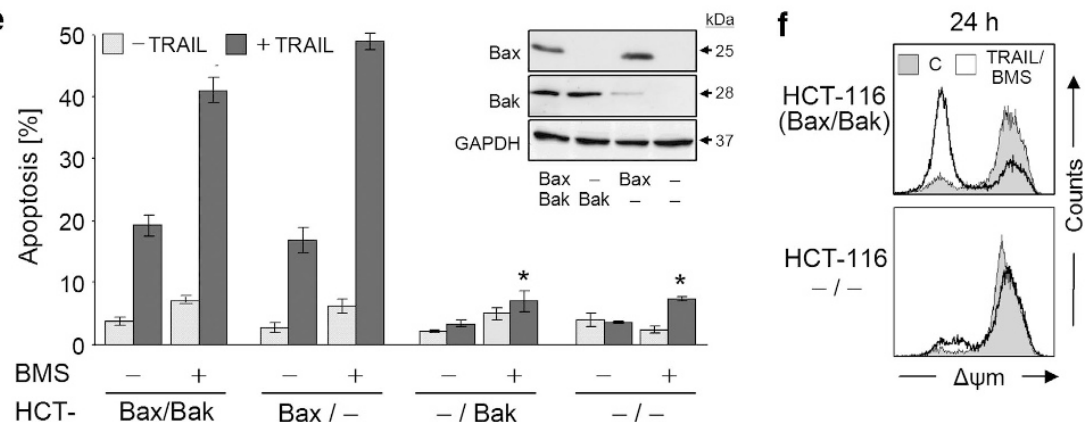

Figure 4 Response of mitochondria to BMS-345541. (a) Loss of $4 \psi \mathrm{m}$ is shown in a time kinetic analysis in A-375 treated for 2-24h with TRAlL (20 ng/ml) and/or BMS-345541 $(2 \mu \mathrm{M})$. In addition, $\Delta \psi \mathrm{m}$ was determined at $24 \mathrm{~h}$ in A-375-TS (5 $\mu \mathrm{M}$ BMS-345541; right panel). Treated cells (open graphs) were compared with DMSO-treated controls (gray). Two independent experiments with triplicates showed highly comparable results. (b) In quantitative analysis, cells with low $\Delta \psi \mathrm{m}$ (upper panel) were compared to cells with fragmented DNA (lower panel). Mean values and S.D.'s of two independent experiments with triplicates are shown. Statistical significance is indicated ( $\left.{ }^{*} P<0.05\right)$. (c, e) Apoptosis induced by $2 \mu \mathrm{M}$ BMS345541 and TRAlL was investigated in (c) A-375 cells stably transfected with Bcl-2 (A375-Bcl-2) and mock-transfected controls, as well as in (e) HCT-116 cells (Bax ${ }^{+}$, Bak ${ }^{+}$) and subclones with knockdown for Bax and/or Bak. Expression of Bcl-2, Bax and Bak was determined by western blotting (insets, GAPDH as loading control). Statistical significant differences to parental cells and mock controls, respectively, are indicated ( $\left.{ }^{*} P<0.05\right)$. (d, $\left.\mathbf{f}\right) \Delta \psi \mathrm{m}$ in response to treatment with BMS-345541 (5 $\left.\mu \mathrm{M}\right)$ and TRAlL ( $\left.20 \mathrm{ng} / \mathrm{ml}\right)$ is shown for indicated cell clones and times. Treated cells (open graphs) were compared with DMSO controls (gray). Each two independent experiments with triplicates showed comparable results 

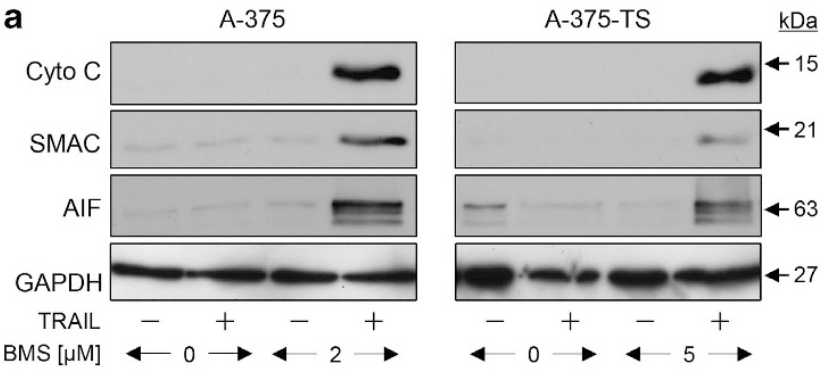

b

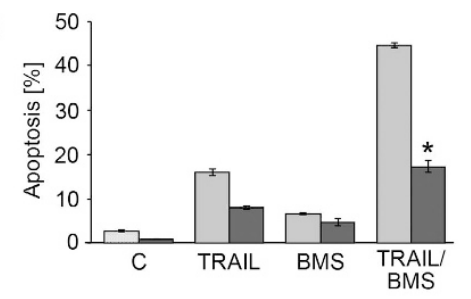

$\square \underset{\text { Mock XIAP }}{\square}$

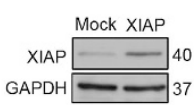

C
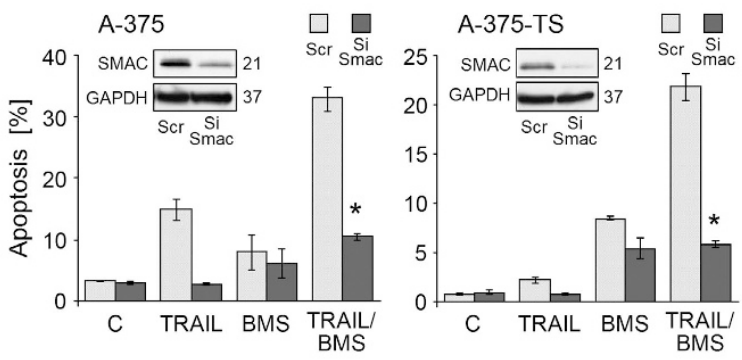

d

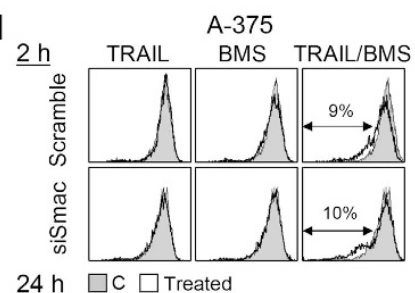

$24 \mathrm{~h} \square \mathrm{C} \square$ Treated

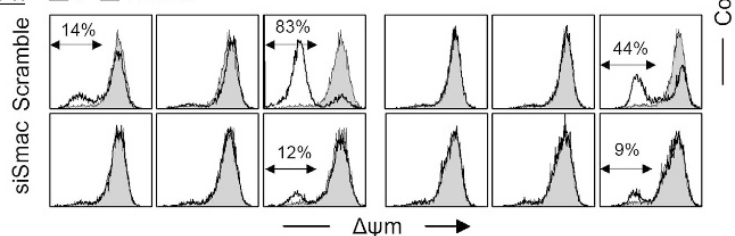

Figure 5 Roles of mitochondrial apoptosis pathways and Smac. (a) Cytosolic extracts of A-375 and A-375-TS treated for $2 \mathrm{~h}$ with TRAIL \pm BMS-345541 (A-375, $2 \mu \mathrm{M}$; A-375-TS, $5 \mu \mathrm{M}$ ) were investigated by western blotting. Equal loading was proven by the cytosolic protein GAPDH. Two independent experiments revealed highly comparable results. (b) The sensitivity of A-375 for BMS-345541/TRAIL-induced apoptosis $(2 \mu \mathrm{M}$ $20 \mu \mathrm{M}$ ) was monitored after transfection of a XIAP-encoding plasmid. Mock-transfected cells are shown as controls. Apoptosis (\% of sub-G1 cells) is shown at $24 \mathrm{~h}$ of treatment Mean values and S.D.'s of a representative experiment (one of two) is shown; each experiment consisted of triplicates. Statistical significance is indicated ( $\left.{ }^{*} P<0.05\right)$, when comparing to mock controls. XIAP expression is shown in an inset. (c) Sensitivity of A-375 and A-375-TS cells for BMS-345541/TRAIL-induced apoptosis (sub-G1 cells, $24 \mathrm{~h}$ treatment) is shown after siRNA-mediated Smac knockdown (dark bars), as compared to respective scramble-siRNA-transfected controls (gray). Smac downregulation is shown in insets (western blotting, GAPDH as control). Mean values and S.D.'s of two independent experiments with triplicates are shown; statistical significance is indicated $\left({ }^{*} P<0.05\right)$, comparing apoptosis after transfection with siRNA against Smac and scramble siRNA. (d) $\Delta 4 \mathrm{~m}$ was determined in A-375 and A-375-TS cells treated for $2 \mathrm{~h}$ or $24 \mathrm{~h}$ with TRAIL $(20 \mathrm{ng} / \mathrm{ml}) \pm \mathrm{BMS}-345541$ (A-375, $2 \mu \mathrm{M}$; A-375-TS, $5 \mu \mathrm{M}$ ). Treated cells (open graphs) were compared with DMSO-treated controls (gray). Two independent experiments with triplicates showed highly comparable results
Bax-deactivating phosphorylation at Ser184 and significant enhancement of the Bax-activating phosphorylation at Thr167 were seen already at $1 \mathrm{~h}$ of BMS-345541 treatment. For control, the signals of a total Bax antibody were not changed by BMS-345541 (Figure 7c). For further controlling the specificity of the assays, signals were analyzed in HCT-116 parental and Bax-KO cells. HCT-116 parental cells showed significant Bax signals with all antibodies (total Bax, pBaxSer184, pBax-Thr176), whereas no signals were seen in Bax-KO cells, thus excluding nonspecific binding (Figure 7c). These assays provided a link between BMS-345541mediated kinase inhibition and Bax activation. Also after $24 \mathrm{~h}$, when strong apoptosis was determined, Bax activation and altered phosphorylation still remained (Figure 7d).

As BMS-345541 was described as NF- $k$ B inhibitor, we wished to distinguish the effects on Bax from NF- $k$ B function. The NF- $\kappa$ B pathway was therefore interrupted by transfection of an $\mathrm{I}-\kappa \mathrm{B} \alpha$ super-repressor $(\mathrm{I}-\kappa \mathrm{B} \alpha-\mathrm{SR})$. Owing to the HA tag, $\mathrm{I}-\kappa \mathrm{B} \alpha-\mathrm{SR}(45 \mathrm{kDa})$ is distinguished from the endogeneous $\mathrm{I}-\kappa \mathrm{B} \alpha(39 \mathrm{kDa})$, and its expression is shown in $\mathrm{A}-375$ after transfection (Figure $7 \mathrm{e}$ ). The NF- $\kappa \mathrm{B}$ inhibitory activity was demonstrated in combination with TNF- $\alpha$. Thus, the increase of nuclear p65 DNA-binding activity, seen in response to TNF- $\alpha$ in mock-transfected A-375, was prevented by $\mathrm{I}-\kappa \mathrm{B} \alpha-$ SR transfection (Figure 7f).

Expression of $\mathrm{I}-\kappa \mathrm{B} \alpha-\mathrm{SR}$ also slightly enhanced TRAILinduced apoptosis; however, the effects of BMS-345541 and $\mathrm{I}-\kappa \mathrm{B} \alpha-\mathrm{SR}$ appeared as independent of each other, as $\mathrm{I}-\kappa \mathrm{B} \alpha-$ SR similarly enhanced BMS-345541/TRAIL-induced apoptosis (Figure 7g). Most important for this study, inbibition of NF- $\kappa$ B by $\mathrm{l}-\kappa \mathrm{B} \alpha-\mathrm{SR}$ remained without effect on Bax activation (Bax-NT) or Bax phosphorylation (Figure 7h).

Based on these findings, a model is suggested explaining sensitization of melanoma cells for TRAIL-induced apoptosis (Figure 8). Accordingly, TRAIL resulted in early caspase-8 activation, but direct apoptosis induction via caspase-3 was blocked by high clAP activities. On the other hand, BMS-345541-mediated kinase inhibition resulted in altered phosphorylation of Bax, leading to Bax activation. However, Bax-induced apoptosis was prevented by $\mathrm{Bcl}-2$. Efficient induction of apoptosis was only possible after combination of both drugs. In this way, TRAIL-induced tBid antagonized $\mathrm{Bcl}-2$, and the pathway for Bax-induced apoptosis was open. This resulted in the release of apoptogenic mitochondrial factors, in particular of Smac, which antagonized clAPs to overcome caspase-3 inhibition (Figure 8).

\section{Discussion}

The death ligand TRAIL represents a promising antitumor strategy as apoptosis is induced in cancer cells, while normal cells are largely spared. ${ }^{21,22}$ However, only limited efficacy of TRAIL receptor agonists has been seen in clinical trials for solid tumors and lymphomas. ${ }^{23-25}$ Non-sufficient efficacy may be attributed to inducible resistance, found in different tumor models, including melanoma cells. ${ }^{6,26}$ Overcoming resistance thus represents a critical step for establishing TRAIL-based therapies, and many approaches are presently tested to reach this goal. ${ }^{27-30}$ 

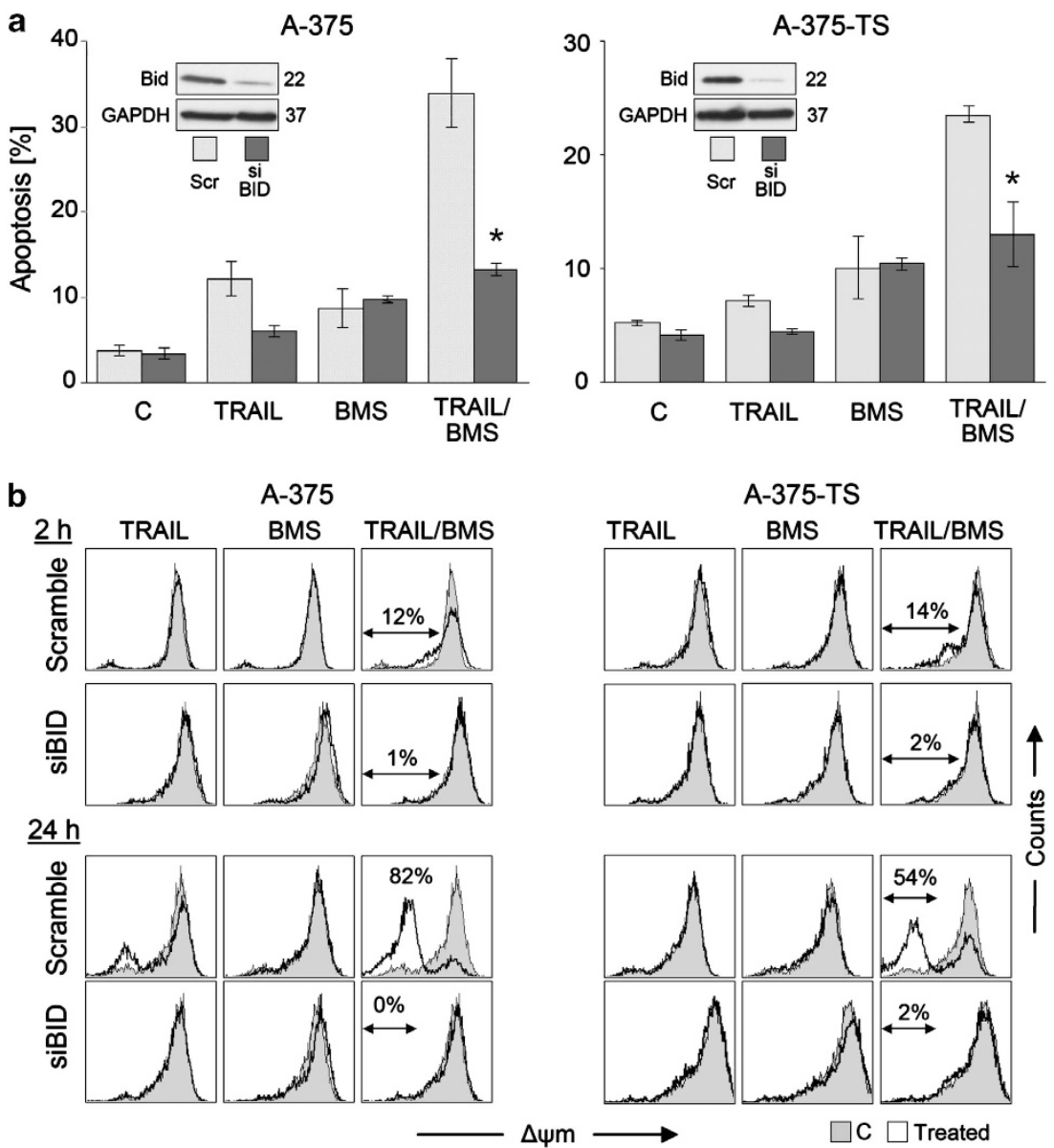

Figure 6 Dependence on Bid. (a) Sensitivity of A-375 and A-375-TS cells for BMS-345541/TRAIL-induced apoptosis (sub-G1 cells, $24 \mathrm{~h}$ treatment) is shown after siRNAmediated Bid knockdown, as compared with the respective scramble-siRNA controls (Scr). Bid downregulation is shown in insets (western blotting, GAPDH as loading control). Mean values and S.D.'s of two independent experiments with triplicates are shown; statistical significance is indicated $\left({ }^{*} P<0.05\right)$, comparing siRNA against Bid with scramble controls. (b) $\Delta \psi \mathrm{m}$ is shown in A-375 and A-375-TS cells treated for $2 \mathrm{~h}$ or $24 \mathrm{~h}$ with TRAlL ( $20 \mathrm{ng} / \mathrm{ml}) \pm \mathrm{BMS}-345541$ (A-375, $2 \mu \mathrm{M} ; \mathrm{A}-375-\mathrm{TS}, 5 \mu \mathrm{M})$. Treated cells (open graphs) were compared with DMSO-treated controls (gray). Two independent experiments with triplicates showed highly comparable results

Apoptosis resistance of cancer cells has also been related to high NF- $\kappa$ B activity resulting from dysregulation of $\mathrm{IKK},{ }^{16}$ and BMS-345541 was described as IKK inhibitor. ${ }^{31}$ Its NF- $\kappa \mathrm{B}$ inhibitory activity was also seen here in combinations with TNF- $\alpha$. This activity may explain direct effects of BMS-345541 at later times. Thus, induction of apoptosis has been reported by BMS-345541 in leukemia cells, ${ }^{20}$ and higher concentrations of BMS-345541 $(10 \mu \mathrm{M})$ have also been reported previously to induce apoptosis in melanoma cells, which was caspase-independent and related to AIF. ${ }^{32}$ Caspase independence of the direct proapoptotic effects of BMS345541 was also seen in this study.

As a main result, low-dose BMS-345541 (2-5 $\mu \mathrm{M})$ did not trigger apoptosis by itself but efficiently enhanced TRAIL-induced apoptosis in melanoma cells, and helped to overcome permanent and inducible TRAIL resistance. Sensitization for TRAIL by BMS-345541 was also shown in colon carcinoma and neuroblastoma cells, which had been related in these cells to NF- $\kappa$ B inhibition. ${ }^{19,33} \mathrm{NF}-\kappa \mathrm{B}$ may even be activated by death receptor signaling, and TRAIL-mediated NF- $\kappa$ B activation has been discussed as a cause of TRAIL resistance in leukemia, cholangiocarcinoma ${ }^{34,35}$ as well as in melanoma cells. ${ }^{18}$ However, no correlation was seen in melanoma cells between inducible TRAIL resistance and $\mathrm{NF}-\kappa \mathrm{B}$ activation. ${ }^{6}$ Also in this study, no early $\mathrm{I}-\kappa \mathrm{B} \alpha$ degradation or early p65 nuclear translocation was seen in response to TRAIL. Thus, the early effects of BMS-345541 in melanoma cells cannot be explained by NF- $\kappa$ B suppression.

As concerning caspase cascades, caspase-8 was already processed in response to TRAIL, despite partially blocked apoptosis. The signal was only weak in permanent resistant cells, but caspase-8 activation not necessarily has to coincide with its processing. Rather, induced proximity at the DISC may correlate with its activity, while processing may be secondary. ${ }^{36}$

The enhancement of mitochondrial apoptosis pathways appeared as characteristic for the combination of BMS$345541 /$ TRAIL, evident by early decrease of $\Delta \psi \mathrm{m}$ and by release of apoptogenic mitochondrial factors. An initiation phase, characterized by loss of $\Delta \psi \mathrm{m}$ before any apoptosis was induced, was distinguished from an amplification phase, when enhanced apoptosis coincided with further decrease of $\Delta \psi \mathrm{m}$. Proving the critical role of mitochondrial pathways, apoptosis was abrogated by overexpression of $\mathrm{Bcl}-2$ or $\mathrm{Bax}$ 
a
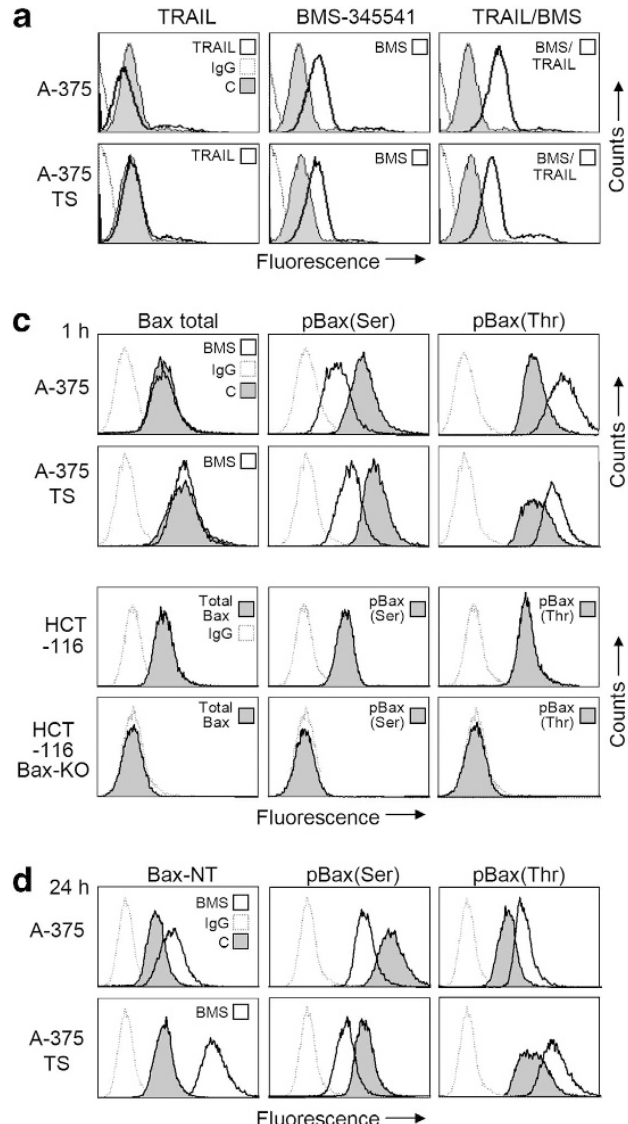

b

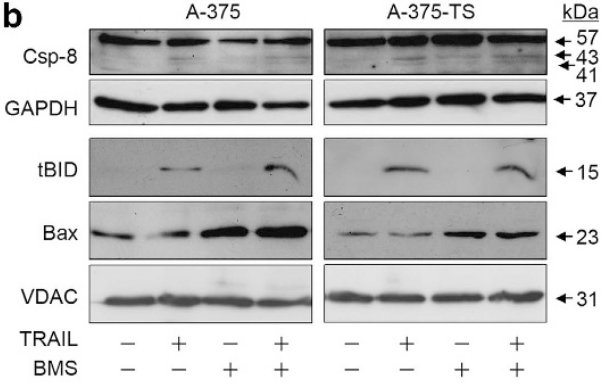

e

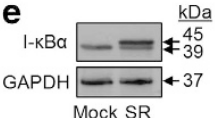

Mock SR
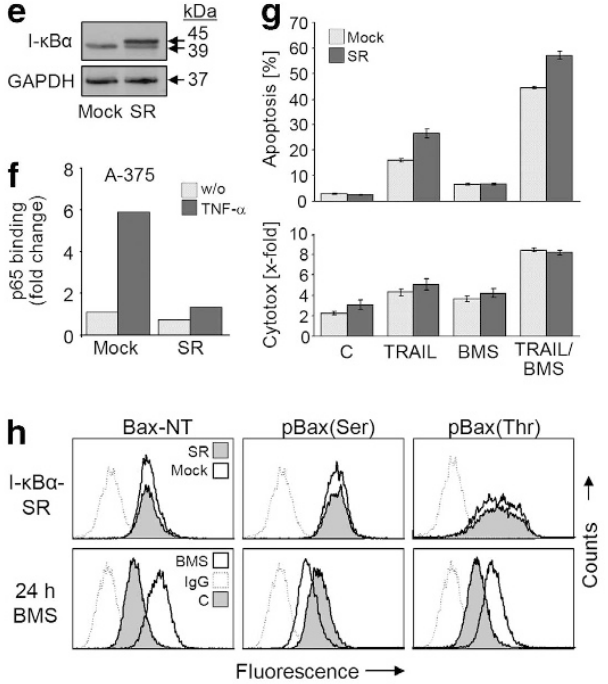

Figure 7 Role of Bax. (a) A-375 and A-375-TS were treated for $1 \mathrm{~h}$ with TRAlL $(20 \mathrm{ng} / \mathrm{ml}) \pm \mathrm{BMS}-345541$ (A-375, $2 \mu \mathrm{M}$; A-375-TS, $5 \mu \mathrm{M})$ and were analyzed for Bax conformational changes by flow cytometry (Bax-NT). (b) Total protein extracts (caspase-8) and mitochondrial extracts (tBid and Bax) of A-375 and A-375-TS treated for $2 \mathrm{~h}$ were investigated by western blotting. Equal loading was proven by GAPDH and the mitochondrial protein VDAC, respectively. (c) A-375 and A-375-TS were treated for $1 \mathrm{~h}$ with BMS-345541 $(2 \mu \mathrm{M} / 5 \mu \mathrm{M})$ and were analyzed by flow cytometry for total Bax, phosphorylated (p)Bax(Ser167) and pBax(Thr184) expression. Below, signals are shown for HCT-116 and HCT-116 Bax-KO cells. (d) A-375 and A-375-TS, treated with the same conditions, were analyzed after $24 \mathrm{~h}$. (e) Protein expression (western blotting) of endogeneous $\mathrm{I}-\kappa \mathrm{B} \alpha(39 \mathrm{kDa})$ and $\mathrm{I}-\kappa \mathrm{B} \alpha-\mathrm{SR}(45 \mathrm{kDa})$ is shown in mock- and $\mathrm{l}-\kappa \mathrm{B} \alpha$-SR-transfected A-375 cells at $24 \mathrm{~h}$. (f) Relative p65 DNA-binding capacity is shown in nuclear extracts of mock- and $\mathrm{I}-\kappa \mathrm{B} \alpha-\mathrm{SR}$-transfected A-375 cells, as quantified by enzyme-linked immunosorbent assay (ELISA) (24 h after transfection, $1 \mathrm{~h}$ treatment with TNF- $\alpha$ ). (g) Apoptosis and cytotoxicity were monitored in mock- or l- $\kappa$ B $\alpha$-SR-transfected A-375 treated in addition with BMS-345541 and/or TRAIL. Treatment with BMS$345541 /$ TRAIL (for $24 \mathrm{~h}$ ) started at $24 \mathrm{~h}$ after transfection. Mean values and S.D.'s of a representative experiment are shown (one of two, each with triplicates). (h) l- $\kappa \mathrm{B} \alpha-\mathrm{SR}$ or mock-transfected A-375 cells were analyzed by flow cytometry at $24 \mathrm{~h}$ for Bax conformational changes (Bax-NT) and for Bax phosphorylation by pBax(Ser167) and pBax(Thr184) antibodies. For control, A-375 cells were treated in parallel for $24 \mathrm{~h}$ with BMS-345541 $(2 \mu \mathrm{M})$ and are shown below. For all flow cytometry data, treated cells are shown in overlays with respective non-treated controls and/or lgG1-stained controls. Always two independent experiments with triplicates revealed highly comparable results

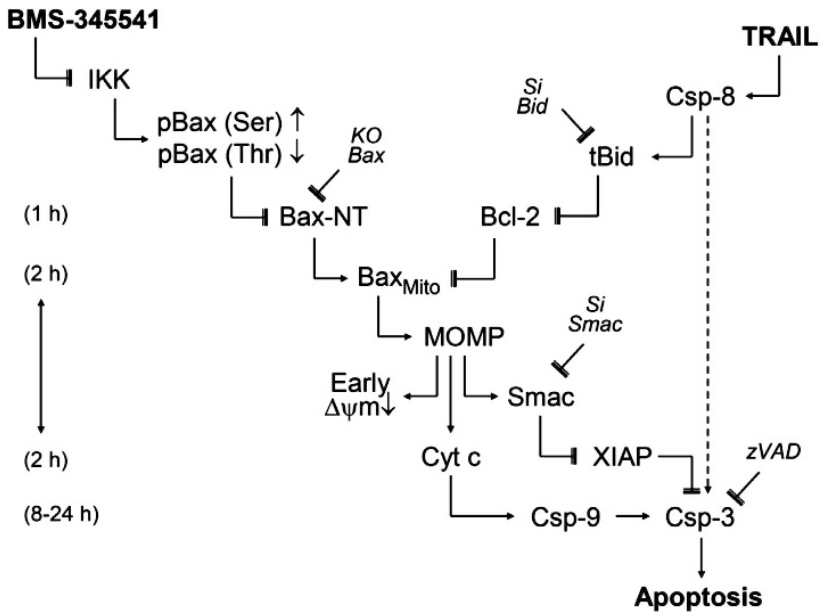

Figure 8 Model of synergistic interaction of TRAIL and BMS-345541. A model of TRAIL and BMS-345541 activities is presented (explanations are given in the text) knockdown. Activation of mitochondrial pathways in melanoma cells in course of the sensitization for TRAIL was also seen for indirubin and UVB. ${ }^{29,30}$

Downregulation of antiapoptotic factors may cause apoptosis; however, the time needs to be considered. Here, Mcl-1 and XIAP were downregulated at $16 \mathrm{~h}$ by BMS-345541/ TRAIL, which may have an impact on amplification of apoptosis at later times. Both proteins were described as caspase-3 targets, ${ }^{29,37}$ and $\mathrm{Mcl}-1$ may also be downregulated by enhanced proteasomal degradation. ${ }^{38}$ In agreement, $\mathrm{Mcl}-1$ and XIAP downregulation was prevented here by caspase inhibition. The NF- $\kappa$ B target cFLIP plays a decisive role in suppressing TRAIL-induced apoptosis, as shown in cutaneous lymphoma, ${ }^{39}$ but it was not regulated by BMS-345541 in melanoma cells.

Inhibitor of apoptosis proteins (clAPs) directly bind caspase- 9 and -3 to prevent caspase-mediated cell death. ${ }^{40}$ In particular, XIAP is considered as an important antiapoptotic 
factor in cancer cells, ${ }^{12}$ and its predominant role has been demonstrated in melanoma. ${ }^{29,41}$ XIAP also exerted a decisive inhibitory function in BMS-345541/TRAIL-induced apoptosis, as its overexpression strongly diminished apoptosis. Owing to the role of XIAP, Smac appeared as a suitable candidate explaining efficient induction of apoptosis by BMS-345541/ TRAIL. Its particular role was proven by siRNA-mediated knockdown, which largely abolished BMS-345541/TRAILinduced apoptosis, whereas remaining apoptosis could be attributed to the effects of BMS-345541 alone. Smac knockdown prevented the loss of $\Delta \psi \mathrm{m}$ in the amplification phase, whereas loss of $\Delta \psi \mathrm{m}$ in the initiation phase was still observed, thus suggesting Smac as downstream in the regulation cascade. The inhibition of XIAP by released Smac appeared to overcome arrested caspase-3. Smac knockdown had also been shown to suppress apoptosis in melanoma cells, when induced by TRAIL in combinations with UVB or a potassium channel inhibitor. ${ }^{29,41}$

The proapoptotic Bcl-2 protein Bid appeared as suitable regulator for explaining the input of death ligands, due to caspase-8-mediated Bid activation. ${ }^{10}$ Indeed, Bid knockdown largely abolished BMS-345541/TRAIL-induced apoptosis. Again, remaining apoptosis could be attributed to the effects of BMS-345541 alone. Bid knockdown prevented loss of $\Delta \psi \mathrm{m}$ in both the amplification and the initiation phase, thus proving its upstream role. Knockdown of Bid had also suppressed apoptosis by TRAIL or TRAIL combinations in colon carcinoma and mesothelioma cells. ${ }^{42,43}$ As Bcl-2 is considered a dominant antiapoptotic factor in melanoma, ${ }^{2,44}$ the main function of Bid may be its inhibitory effect on Bcl-2. ${ }^{14}$

The experiments were suggestive for a decisive role of Bax, seen by its mitochondrial translocation and conformational changes. Even low doses of BMS-345541, applied here, resulted in strong Bax activation, which notably appeared as an early effect (1-2h). Previous studies demonstrating Bax activation by BMS-345541 did not clearly distinguish between early and delayed effects. ${ }^{20,32}$ Release of AIF that had been reported at $4 \mathrm{~h}$ in response to high-dose BMS-345541 in melanoma cells may be related to its caspase-independent, direct effects, ${ }^{32}$ but early Bax activation demonstrated here explains the sensitization for TRAIL.

The key, how Bax is activated, represents an important and largely open question, which is of general interest in apoptosis research. Bax-inactivating phosphorylation at Ser184 and its activating phosphorylation at Thr167 have been discussed. ${ }^{45,46}$ So far, indirect assays based on immunopreciptation had been occasionally applied for addressing this question. ${ }^{45,47-49}$ Here, new direct assays are introduced, which are based on cell permeabilization, Bax phosphorylation-specific antibodies and flow cytometry. These supplied a comprehensive overview on the phosphorylation status of Bax before and after BMS-345541 treatment.

Thus, Bax activation by BMS-345541 tightly correlated with suppressed phosphorylation at Ser184 and enhanced phosphorylation at Thr167, which both appeared as immediate effects $(1 \mathrm{~h})$. Different kinases may be responsible here. Thus, IKK $\beta$ has been shown to phosphorylate antiapoptotic $\mathrm{Bcl}-2$ proteins $\left(\mathrm{Bcl}-2\right.$ and $\left.\mathrm{Bcl}-\mathrm{x}_{\mathrm{L}}\right)$, leading to their inactivation. ${ }^{50,51}$ Also, Akt may phosphorylate Bax at Ser184, ${ }^{47,48}$ whereas this site is dephosporylated by protein phosphatase
PP2A. ${ }^{52}$ Phosphorylation of Thr167 had been related to JNK and p38 pathways in hepatoma and retinoblastoma cells when treated with staurosporine or chemotherapeutics. ${ }^{45,53}$ JNK may also be inactivated by $\operatorname{IKK} \beta .^{54}$ Furthermore, Bax phosphorylation at Thr167 may be mediated via the ERK pathway as reported in eosinophils; ${ }^{49}$ activation of ERK by BMS-345541 has also been reported in melanoma cells. ${ }^{55}$ As shown here, the effects of BMS-345541 on Bax were clearly distinct from NF- $\kappa \mathrm{B}$ function, as NF- $\kappa \mathrm{B}$ inhibition by an $\mathrm{I}-\kappa \mathrm{B} \alpha$ super-repressor remained without effect on Bax phosphorylation.

In conclusion, suppressed responsiveness of melanoma cells to TRAIL appeared as based on three main antiapoptotic regulation steps, namely (i) high levels of antiapoptotic Bcl-2 proteins, (ii) high levels of clAPs and (iii) suppressed Bax activation. Efficient induction of apoptosis by TRAIL/BMS345541 was possible because of antagonizing Bcl-2 by tBid and direct activation of Bax by its altered phosphorylation. Importantly, mitochondrial tBid was also seen in A-375 and A-375-TS in response to TRAIL alone, and Bax was activated in response to BMS-345541 alone. However, only in combination, they resulted in Smac release, which antagonized clAPs to open the caspase cascade and allowed efficient induction of apoptosis.

The kinase inhibitor BMS-345541 has shown efficacy in mouse models ${ }^{55}$ as well as in ex vivo leukemia cells. ${ }^{20}$ Also in combinations, BMS-345541 or other IKK inhibitors enhanced the antitumor activity of cytostatic agents and death ligands. ${ }^{19,20,33,55,56}$ These effects have so far been related to an inhibition of the antiapoptotic functions of NF- $\kappa \mathrm{B}$. Here, an additional function of BMS-345541 was identified, which may be of particular significance for apoptosis regulation, namely its activation of Bax. This effect of BMS-345541 was clearly distinct from NF- $\kappa \mathrm{B}$ function. Thus, modulation of the Bax phosphorylation level appears as a highly suitable strategy for enhancing TRAIL sensitivity of melanoma cells, and therapeutic strategies may be considered.

\section{Materials and Methods}

Cell culture. Human melanoma cell lines enclosed TRAIL-sensitive (A-375, Mel-HO) and -resistant cells (Mel-2a and MeWo). ${ }^{5}$ Sublines with induced TRAIL resistance (Mel-HO-TS, A-375-TS) derived from selection with $100 \mathrm{ng} / \mathrm{ml}$ TRAlL. ${ }^{6}$ Other A-375 subclones had been stably transfected with a pIRES-Bcl-2 plasmid (A375-Bcl-2) or pIRES empty plasmid (A375-mock), as described previously. ${ }^{57}$ Parental HCT-116 colon carcinoma cells were derived from ATCC (Maryland, MD, USA). The HCT-116 Bax-KO, Bak-knockdown and Bax/Bak-double knockdown cells were kindly provided by B Vogelstein (John Hopkins Cancer Center, Baltimore, MD, USA) and had been described previously. ${ }^{43}$ Cells were cultivated at $37{ }^{\circ} \mathrm{C}, 5 \% \mathrm{CO}_{2}$ in DMEM (4.5 g/l glucose; Gibco, Invitrogen, Karlsruhe, Germany) with 10\% FCS and antibiotics (Biochrom, Berlin, Germany). TRAIL-selected cells were continuously kept with $5 \mathrm{ng} / \mathrm{ml}$ TRAIL until $24 \mathrm{~h}$ before treatment. Cells were plated in 6-, 24- or 96-well plates with $2 \times 10^{5}, 5 \times 10^{4}$ and $5 \times 10^{3}$ cells, respectively, and treatment was started after $24 \mathrm{~h}$.

For induction of apoptosis, the following agents were used: TRAIL (Alexis, Gruenberg, Germany; ALX-201-073-C020, $20 \mathrm{ng} / \mathrm{ml}$ ); the agonistic monoclonal CD95 antibody CH-11 (Beckman Coulter, Marseille, France; PN IM 1504; $50 \mathrm{ng} / \mathrm{ml}$ ); TNF- $\alpha$ (10 ng/ml; Sigma-Aldrich, Taufkirchen, Germany) and the IKK inhibitor BMS345541 (2-10 $\mu \mathrm{M}$; Sigma-Aldrich). For caspase inhibition, cells were preincubated for $1 \mathrm{~h}$ with $10 \mu \mathrm{M}$ of the pancaspase inhibitor zVAD-fmk (R\&D Systems, Wiesbaden, Germany).

Cell proliferation, apoptosis and cytotoxicity. For continuous monitoring of cell growth, the xCELLigence system (Roche Diagnostics, 
Mannheim, Germany) was applied, and relative cell indices were determined, which correspond to attached cell numbers. For quantification of apoptosis, cell cycle analyses were performed ${ }^{58}$ Cells harvested by trypsinization were stained for $1 \mathrm{~h}$ with propidium iodide (Sigma-Aldrich; $200 \mathrm{mg} / \mathrm{ml}$ ), and sub-G1 fractions corresponding to cells with fragmented DNA were quantified by flow cytometry (FACS Calibur; BD Bioscience, Bedford, MA, USA). Cytotoxicity was determined in parallel by measuring LDH activity in culture fluids applying a cytotoxicity detection assay (Roche Diagnostics). $\Delta \psi \mathrm{m}$ was determined with the fluorescent dye $\mathrm{TMRM}^{+}$(tetramethylrhodamine methyl ester perchlorate; Sigma-Aldrich; $1 \mathrm{mM})$. Cells harvested by trypsinization were stained for $15 \mathrm{~min}$ at $37^{\circ} \mathrm{C}$ and analyzed by flow cytometry.

For identification of chromatin condensation and nuclear fragmentation in course of apoptosis, cells were harvested by trypsinization, centrifuged on cytospins and fixed for $30 \mathrm{~min}$ in $4 \%$ formaldehyde. Cytospins were stained with bisbenzimide (Hoechst-33258; Sigma-Aldrich; $1 \mathrm{mg} / \mathrm{ml}, 30 \mathrm{~min}$ ) and examined by fluorescence microscopy. Apoptotic cells were identified by fragmented nuclei or by bright bluestained nuclei with condensed chromatin.

Plasmid transfection. For transient overexpression, cells were transfected for $4 \mathrm{~h}$ at $37^{\circ} \mathrm{C}$ with $2.5 \mu \mathrm{g} / \mathrm{ml}$ plasmid DNA and $0.1 \%$ DMRIE-C (Invitrogen) in Opti-MEM medium (Life Technologies, Carlsbad, CA, USA). A pCMV-Sport6 plasmid with the full-length sequence of human XIAP (IRATp970H0655D; Source BioScience imaGenes, Berlin, Germany) and the pcDNA3 plasmid with the sequence of an HA-tagged $\mathrm{I}-\kappa \mathrm{B} \alpha$ super-repressor were used (pcDNA3-HA$I_{\kappa} \mathrm{B} \alpha$-super-repressor; BCCM, Brussels, Belgium). The plasmid pcDNA3.1 (Invitrogen) served as mock control. This $1-\kappa \mathrm{B} \alpha$ mutant cannot be phosphorylated by IKK and can thus not be downregulated. ${ }^{59}$

Assays for Bax phosphorylation and Bax activation. For the analysis of Bax phosphorylation related to its activation, assays were established for flow cytometry analysis of phospho-Bax (Ser184) and phospho-Bax (Thr167). Cells $\left(10^{5}\right)$ were harvested by trypsinization and fixed for $30 \mathrm{~min}$ with $4 \%$ paraformaldehyde in PBS. Cells were then incubated with the respective antibodies in PBS $/ 1 \%$ FCS for $1 \mathrm{~h}$ at $4{ }^{\circ} \mathrm{C}$. This buffer also contained $0.1 \%$ saponin for cell permeabilization. The following antibodies were used: phosphoBax (Thr167) (A0773; Assay Biotechnology, Sunnyvale, CA, USA; 1:300) and phospho-Bax (Ser184) (A8297; Assay Biotechnology; 1:50); and an antibody against total Bax (sc-493; Santa Cruz Biotechnology, Santa Cruz, CA, USA; rabbit, 1:300) was applied as control. Cells were subsequently incubated for $1 \mathrm{~h}$ at $4{ }^{\circ} \mathrm{C}$ in the dark with the secondary antibody: goat anti-rabbit IgG $(\mathrm{H}+\mathrm{L})-\mathrm{FITC}$ (Jackson Immuno Research, West Grove, PA, USA). After washing and resuspension in PBS $/ 1 \% \mathrm{FCS}$, cells were immediately measured by flow cytometry.

For analysis of Bax conformational changes related to its activation, a primary antibody specific for the Bax N-terminal domain was applied in flow cytometry (Bax-NT; rabbit; Upstate, Lake Placid, NY, USA; no. 06-499). According to the protocol described above, $10^{5}$ cells were harvested by trypsinization, fixed with $4 \%$ paraformaldehyde and incubated for $1 \mathrm{~h}$ at $4{ }^{\circ} \mathrm{C}$ with the Bax-NT antibody $(1: 100)$ in $\mathrm{PBS} / 1 \% \mathrm{FCS}+0.1 \%$ saponin. After incubation with the secondary antibody (goat anti-rabbit IgG $(\mathrm{H}+\mathrm{L})$-FITC; Jackson Immuno Research), washing and resuspension in $\mathrm{PBS} / 1 \% \mathrm{FCS}$, cells were measured by flow cytometry.

siRNA transfection. Transient cell transfection was performed in 6-well plates at $24 \mathrm{~h}$ after seeding (70\% confluence); BMS-345541/TRAIL treatment was followed after another $24 \mathrm{~h}$. Amounts of $20 \mathrm{pmol}$ siRNA and $4 \mu \mathrm{l}$ TurboFect (Fermentas, St. Leon-Rot, Germany) were used per well. The siRNAs for Smac (sc-36505), Bid (sc-29800) and the scrambled control (sc-37007) were derived from Santa Cruz Biotechnology.

Expression analysis. For western blotting, total protein extracts were obtained by cell lysis in $150 \mathrm{mM} \mathrm{NaCl}, 1 \mathrm{mM}$ EDTA, $2 \mathrm{mM}$ PMSF, $1 \mathrm{mM}$ leupeptin $1 \mathrm{mM}$ pepstatin, $0.5 \%$ SDS, $0.5 \%$ NP-40 and $10 \mathrm{mM}$ Tris- $\mathrm{HCl}(\mathrm{pH}$ 7.5). Cytosolic and mitochondrial cell fractions were obtained by a kit of PromoKine (Heidelberg, Germany). Western blotting on nitrocellulose membranes has been described previously. ${ }^{60}$

Primary antibodies were from Cell Signaling (Danvers, MA, USA): cleaved caspase-3 (3664, rabbit, 1:5000), caspase-3 (9662, rabbit, 1:1000), caspase-8 (9746, mouse, $1: 1000)$, caspase-9 (9505, rabbit, 1:1000) and XIAP (2042, rabbit, $1: 1000$ ). Primary antibodies were from Santa Cruz Biotechnology: I- $\kappa \mathrm{B} \alpha$ (sc-371, rabbit, 1:400), p65 (sc-109, rabbit), Mcl-1 (sc-12756, mouse, 1:200), Bcl-2 (sc-
783, rabbit; $1: 200$ ), Bax (sc-493, rabbit, $1: 200$ ), Bak (sc-893, rabbit, 1:500), survivin (sc-17779, mouse, 1:500), AIF (sc-9416, goat, 1: 1000), Smac (sc-56230, mouse, 1: 1000), Bid (sc-2002, rabbit, 1:1000), c-FLIP $/$ S (G-11, sc-5276 (Santa Cruz Biotechnology), 1:200) and glucose-6-phosphate dehydrogenase (GAPDH) (sc-3233, mouse, 1: 1000). Further antibodies: cytochrome c (BD Biosciences; 529536, mouse, no. 556433, 1:1000), voltage-dependent anion channel (VDAC) (Calbiochem, Nottingham, UK; mouse, 1:5000). Secondary antibodies were : peroxidase-labeled goat anti-rabbit, goat anti-mouse and rabbit anti-goat (Dako, Hamburg, Germany; 1:5000)

NF- $\kappa$ B activity. Nuclear translocation of $p 65 \mathrm{NF}-\kappa \mathrm{B}$ subunit was determined by western blotting of nuclear extracts, generated by a nuclear extraction kit (no. 40010; Active Motif, Rixensart, Belgium). Protein contents were quantified by BCA reagent (Pierce, Bonn, Germany). The DNA-binding capacity of NF- $\kappa$ B was determined by a NF- $\kappa$ B family ELISA kit (Active Motif). Therefore, $6 \mathrm{mg}$ of nuclear extracts obtained from $10^{7}$ cells were placed in 96 -well plates coated with oligonucleotides covering the NF- $k \mathrm{~B}$ consensus sequence. Binding of p65 was determined by a specific antibody, followed by immunostaining with a horseradish peroxidase-labeled secondary antibody and measurement at $450 \mathrm{~nm}$ in an ELISA reader.

Statistical analyses. Assays consisted of triplicates, and at least two independent experiments were performed. Mean values and S.D.'s were either calculated by enclosing all individual values of the independent experiments (at least six values) or a representative experiment is shown (triplicate values). Statistical significance was proven by Student's $t$-test (normal distribution), and $P$-values of $<0.05$ were considered as statistically significant.

\section{Conflict of Interest}

The authors declare no conflict of interest.

Acknowledgements. The study was supported by the German Cancer Aid (Deutsche Krebshilfe), Melanomverbund, 10-8008, TP7.

1. Garbe C, Leiter U. Melanoma epidemiology and trends. Clin Dermatol 2009; 27: 3-9.

2. Eberle J, Kurbanov BM, Hossini AM, Trefzer U, Fecker LF. Overcoming apoptosis deficiency of melanoma - Hope for new therapeutic approaches. Drug Resist Update 2007; 10: 218-234.

3. Soengas MS, Lowe SW. Apoptosis and melanoma chemoresistance. Oncogene 2003; 22: 3138-3151

4. Newsom-Davis T, Prieske S, Walczak H. Is TRAIL the holy grail of cancer therapy? Apoptosis 2009; 14: 607-623.

5. Kurbanov BM, Geilen CC, Fecker LF, Orfanos CE, Eberle J. Efficient TRAIL-R1/DR4mediated apoptosis in melanoma cells by tumor necrosis factor-related apoptosis-inducing ligand (TRAIL). J Invest Dermatol 2005; 125: 1010-1019.

6. Kurbanov BM, Fecker LF, Geilen CC. Sterry W, Eberle J. Resistance of melanoma cells to TRAIL does not result from upregulation of antiapoptotic proteins by NF-kappa B but is related to downregulation of initiator caspases and DR4. Oncogene 2007; 26: 3364-3377.

7. Zhang XD, Wu JJ, Gillespie S, Borrow J, Hersey P. Human melanoma cells selected for resistance to apoptosis by prolonged exposure to tumor necrosis factor-related apoptosisinducing ligand are more vulnerable to necrotic cell death induced by cisplatin. Clin Cancer Res 2006; 12: 1355-1364.

8. Krammer PH, Arnold R, Lavrik IN. Life and death in peripheral T cells. Nat Rev Immunol 2007; 7: 532-542

9. Sheridan C, Brumatti G, Elgendy M, Brunet M, Martin SJ. An ERK-dependent pathway to Noxa expression regulates apoptosis by platinum-based chemotherapeutic drugs. Oncogene 2010; 29: 6428-6441.

10. Li HL, Zhu H, Xu CJ, Yuan J. Cleavage of BID by caspase 8 mediates the mitochondrial damage in the Fas pathway of apoptosis. Cell 1998; 94: 491-501.

11. Tait SWG, Green DR. Mitochondria and cell death: outer membrane permeabilization and beyond. Nat Rev Mol Cell Biol 2010; 11: 621-632.

12. Fulda S, Vucic D. Targeting IAP proteins for therapeutic intervention in cancer. Nat Rev Drug Discov 2012; 11: 109-124.

13. Norberg E, Orrenius S, Zhivotovsky B. Mitochondrial regulation of cell death: processing of apoptosis-inducing factor (AIF). Biochem Biophys Res Commun 2010; 396: 95-100.

14. Chipuk JE, Moldoveanu T, Llambi F, Parsons MJ, Green DR. The BCL-2 family reunion. Mol Cell 2010; 37: 299-310.

15. Fischer U, Janicke RU, Schulze-Osthoff K. Many cuts to ruin: a comprehensive update of caspase substrates. Cell Death Differ 2003; 10: 76-100. 
16. Ben Neriah Y, Karin M. Inflammation meets cancer, with NF-kappa B as the matchmaker. Nat Immunol 2011; 12: 715-723.

17. Nakanishi C, Toi M. Nuclear factor-kappa B inhibitors as sensitizers to anticancer drugs. Nat Rev Cancer 2005; 5: 297-309.

18. Franco AV, Zhang XD, Van Berkel E, Sanders JE, Zhang XY, Thomas WD et al. The role of NF-kappa B in TNF-related apoptosis-inducing ligand (TRAIL)-induced apoptosis of melanoma cells. J Immunol 2001; 166: 5337-5345.

19. Ammann JU, Haag C, Kasperczyk H, Debatin KM, Fulda S. Sensitization of neuroblastoma cells for TRAIL-induced apoptosis by NF-kappa B inhibition. Int J Cancer 2009; 124: 1301-1311.

20. Lopez-Guerra M, Roue G, Perez-Galan P, Alonso R, Villamor N, Montserrat E et al. p65 Activity and ZAP-70 status predict the sensitivity of chronic lymphocytic leukemia cells to the selective I kappa B kinase inhibitor BMS-345541. Clin Cancer Res 2009; 15: 2767-2776.

21. Ashkenazi A. Targeting death and decoy receptors of the tumour-necrosis factor superfamily. Nat Rev Cancer 2002; 2: 420-430.

22. Walczak H, Miller RE, Ariail K, Gliniak B, Griffith TS, Kubin M et al. Tumoricidal activity of tumor necrosis factor related apoptosis-inducing ligand in vivo. Nat Med 1999; 5: 157-163.

23. Younes A, Vose JM, Zelenetz AD, Smith MR, Burris HA, Ansell SM et al. A phase 1b/2 trial of mapatumumab in patients with relapsed/refractory non-Hodgkin's lymphoma. Br J Cancer 2010; 103: 1783-1787.

24. Herbst RS, Eckhardt SG, Kurzrock R, Ebbinghaus S, O'Dwyer PJ, Gordon MS et al. Phase I dose-escalation study of recombinant human Apo2L/TRAIL, a dual proapoptotic receptor agonist, in patients with advanced cancer. J Clin Oncol 2010; 28: 2839-2846.

25. Soria JC, Mark Z, Zatloukal P, Szima B, Albert I, Juhász E et al. Randomized phase II study of dulanermin in combination with paclitaxel, carboplatin, and bevacizumab in advanced non-small-cell lung cancer. J Clin Oncol 2011; 29: 4442-4451.

26. Li Y, Wang H, Wang Z, Makhija S, Buchsbaum D, LoBuglio A et al. Inducible resistance of tumor cells to tumor necrosis factor-related apoptosis-inducing ligand receptor 2-mediated apoptosis by generation of a blockade at the death domain function. Cancer Res 2006; 66 : 8520-8528.

27. Jiang CC, Chen LH, Gillespie S, Kiejda KA, Mhaidat N, Wang YF et al. Tunicamycin sensitizes human melanoma cells to tumor necrosis factor-related apoptosis-inducing ligand-induced apoptosis by up-regulation of TRAIL-R2 via the unfolded protein response. Cancer Res 2007; 67: 5880-5888.

28. Ivanov VN, Partridge MA, Johnson GE, Huang SX, Zhou H, Hei TK. Resveratrol sensitizes melanomas to TRAIL through modulation of antiapoptotic gene expression. Exp Cell Res 2008; 314: 1163-1176.

29. Hornle M, Peters N, Thayaparasingham B, Vörsmann H, Kashkar H, Kulms D. Caspase-3 cleaves XIAP in a positive feedback loop to sensitize melanoma cells to TRAIL-induced apoptosis. Oncogene 2011; 30: 575-587.

30. Berger A, Quast SA, Plotz M, Hein M, Kunz M, Langer P et al. Sensitization of melanoma cells for death ligand-induced apoptosis by an indirubin derivative - enhancement of both extrinsic and intrinsic apoptosis pathways. Biochem Pharmacol 2011; 81: 71-81.

31. Burke JR, Pattoli MA, Gregor KR, Brassil PJ, MacMaster JF, McIntyre KW et al. BMS345541 is a highly selective inhibitor of I kappa B kinase that binds at an allosteric site of the enzyme and blocks NF-kappa B-dependent transcription in mice. J Biol Chem 2003; 278 : 1450-1456.

32. Yang JM, Amiri KI, Burke JR, Schmid JA, Richmond A. BMS-345541 targets inhibitor of kappa B kinase and induces apoptosis in melanoma: Involvement of nuclear factor kappa B and mitochondria pathways. Clin Cancer Res 2006; 12: 950-960.

33. Jani TS, DeVecchio J, Mazumdar T, Agyeman A, Houghton JA. Inhibition of NF-kappa B signaling by quinacrine is cytotoxic to human colon carcinoma cell lines and is synergistic in combination with tumor necrosis factor-related apoptosis-inducing ligand (TRAIL) or oxaliplatin. J Biol Chem 2010; 285: 19162-19172.

34. Falschlehner $\mathrm{C}$, Emmerich $\mathrm{CH}$, Gerlach $\mathrm{B}$, Walczak $\mathrm{H}$. TRAIL signalling: decisions between life and death. Int J Biochem Cell Biol 2007; 39: 1462-1475.

35. Ehrhardt H, Fulda S, Schmid I, Hiscott J, Debatin KM, Jeremias I. TRAIL induced survival and proliferation in cancer cells resistant towards TRAIL-induced apoptosis mediated by NF-kappa B. Oncogene 2003; 22: 3842-3852.

36. Muzio M, Stockwell BR, Stennicke HR, Salvesen GS, Dixit VM. An induced proximity model for caspase-8 activation. J Biol Chem 1998; 273: 2926-2930.

37. Weng CJ, Li Y, Xu D, Shi Y, Tang H. Specific cleavage of Mcl-1 by caspase-3 in tumor necrosis factor-related apoptosis-inducing ligand (TRAIL)-induced apoptosis in Jurkat leukemia T cells. J Biol Chem 2005; 280: 10491-10500.

38. Jacquemin G, Granci V, Gallouet AS, Garrido C, Guillaudeux T, Micheau O et al. Quercetinmediated Mcl-1 and survivin downregulation restores TRAIL-induced apoptosis in non-Hodgkin's lymphoma B cells. Haematol-Hematol J 2012; 97: 38-46.
39. Braun FK, Al Yacoub N, Plotz M, Möbs M, Sterry W, Eberle J. Nonsteroidal antiinflammatory drugs induce apoptosis in cutaneous T-cell lymphoma cells and enhance their sensitivity for TNF-related apoptosis-inducing ligand. J Invest Dermatol 2012; 132: 429-439.

40. Mannhold R, Fulda S, Carosati E. IAP antagonists: promising candidates for cancer therapy. Drug Discov Today 2010; 15: 210-219.

41. Quast S, Berger A, Buttstädt N, Friebel K, Schönherr R, Eberle J. General sensitization of melanoma cells for TRAIL-induced apoptosis by the potassium channel inhibitor TRAM-34 depends on release of SMAC. PLoS One 2012; 7: e39290.

42. Broaddus VC, Dansen TB, Abayasiriwardana KS, Swigart LB, Hunt AE, Evan Gl et al. Bid mediates apoptotic synergy between tumor necrosis factor-related apoptosis-inducing ligand (TRAIL) and DNA damage. J Biol Chem 2005; 280: 12486-12493.

43. Gillissen B, Wendt J, Richter A, Gebhardt N, Preissner R, Belka C et al. Endogenous Bak inhibitors $\mathrm{Mcl}-1$ and $\mathrm{Bcl}-\mathrm{x}(\mathrm{L})$ : differential impact on TRAIL resistance in Bax-deficient carcinoma. J Cell Biol 2010; 188: 851-862.

44. Jansen B, Wacheck V, Heere-Ress E, Schlagbauer-Wadl H, Hoeller C, Lucas $T$ et al. Chemosensitisation of malignant melanoma by BCL2 antisense therapy. Lancet 2000; 356: 1728-1733.

45. Kim BJ, Ryu SW, Song BJ. JNK- and p38 kinase-mediated phosphorylation of Bax leads to its activation and mitochondrial translocation and to apoptosis of human hepatoma HepG2 cells. J Biol Chem 2006; 281: 21256-21265.

46. Renault TT, Manon S. Bax: addressed to kill. Biochimie 2011; 93: 1379-1391.

47. Gardai SJ, Hildeman DA, Frankel SK, Borregaard N, Marrack P, Bratton DL et al. Phosphorylation of Bax Ser(184) by Akt regulates its activity and apoptosis in neutrophils. J Biol Chem 2004; 279: 21085-21095.

48. Xin MG, Deng XM. Nicotine inactivation of the proapoptotic function of Bax through phosphorylation. J Biol Chem 2005; 280: 10781-10789.

49. Shen ZJ, Esnault S, Schinzel A, Borner C, Malter JS. The peptidyl-prolyl isomerase Pin1 facilitates cytokine-induced survival of eosinophils by suppressing Bax activation. Nat Immunol 2009; 10: 257-265.

50. Khoshnan A, Ko J, Tescu S, Brundin P, Patterson PH. IKK alpha and IKK beta regulation of DNA damage-induced cleavage of huntingtin. PLoS One 2009; 4: e5768.

51. Bodur C, Kutuk O, Tezil T, Basaga H. Inactivation of Bcl-2 through IkappaB kinase (IKK)dependent phosphorylation mediates apoptosis upon exposure to 4-hydroxynonenal (HNE). J Cell Physiol 2012; 227: 3556-3565.

52. Xin MG, Deng XM. Protein phosphatase $2 A$ enhances the proapoptotic function of Bax through dephosphorylation. J Biol Chem 2006; 281: 18859-18867.

53. Min H, Ghatnekar GS, Ghatnekar AV, Bu S, Shen B, Huang Q et al. 2-Methoxyestradiol induced bax phosphorylation and apoptosis in human retinoblastoma cells via p38 MAPK activation. Mol Carcinog 2011; 51: 576-585.

54. Deng HB, Mao GX, Zhang JP, Wang Z, Li D. IKK antagonizes activation-induced cell death of CD4 (+) T cells in aged mice via inhibition of JNK activation. Mol Immunol 2010; 48: 287-293.

55. Yang JM, Zaja-Milatovic S, Thu YM, Lee F, Smykla R, Richmond A. Molecular determinants of melanoma malignancy: selecting targets for improved efficacy of chemotherapy. Mol Cancer Ther 2009; 8: 636-647.

56. Schön M, Wienrich BG, Kneitz S, Vöhringer V, Weber O, Stiewe T et al. KINK-1, a novel small-molecule inhibitor of IKK beta, and the susceptibility of melanoma cells to antitumoral treatment. J Natl Cancer Inst 2008; 100: 862-875.

57. Raisova M, Hossini A, Eberle J, Riebeling C, Wieder T, Sturm I et al. Apoptosis resistance in human melanoma cells. J Invest Dermatol 2001; 117: 168.

58. Riccardi C, Nicoletti I. Analysis of apoptosis by propidium iodide staining and flow cytometry. Nat Protoc 2006; 1: 1458-1461.

59. Habraken Y, Piret B, Piette J. S phase dependence and involvement of NF-kappaB activating kinase to NF-kappaB activation by camptothecin. Biochem Pharmacol 2001; 62 : 603-616.

60. Eberle J, Fecker LF, Hossini AM, Daniel PT, Orfanos CE, Geilen CC et al. CD95/Fas signaling in human melanoma cells: conditional expression of CD95L/FasL overcomes the intrinsic apoptosis resistance of malignant melanoma and inhibits growth and progression of human melanoma xenotransplants. Oncogene 2003; 22: 9131-9141.

Cell Death and Disease is an open-access journal published by Nature Publishing Group. This work is licensed under the Creative Commons Attribution-NonCommercial-No Derivative Works 3.0 Unported License. To view a copy of this license, visit http://creativecommons.org/licenses/by-nc-nd/3.0/ 